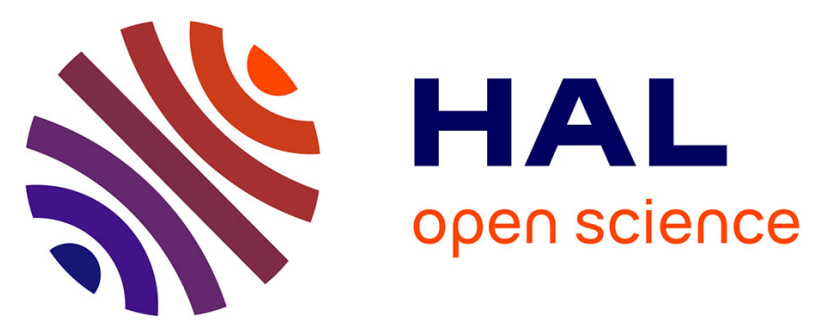

\title{
Eruption type probability and eruption source parameters at Cotopaxi and Guagua Pichincha volcanoes (Ecuador) with uncertainty quantification
}

Alessandro Tadini, Olivier Roche, Pablo Samaniego, Nourddine Azzaoui, Andrea Bevilacqua, Arnaud Guillin, Mathieu Gouhier, Benjamin Bernard, Willy Aspinall, Silvana Hidalgo, et al.

\section{To cite this version:}

Alessandro Tadini, Olivier Roche, Pablo Samaniego, Nourddine Azzaoui, Andrea Bevilacqua, et al.. Eruption type probability and eruption source parameters at Cotopaxi and Guagua Pichincha volcanoes (Ecuador) with uncertainty quantification. Bulletin of Volcanology, 2021, 83 (5), 10.1007/s00445-021-01458-z . hal-03208239

\section{HAL Id: hal-03208239 \\ https://hal.uca.fr/hal-03208239}

Submitted on 27 Apr 2021

HAL is a multi-disciplinary open access archive for the deposit and dissemination of scientific research documents, whether they are published or not. The documents may come from teaching and research institutions in France or abroad, or from public or private research centers.
L'archive ouverte pluridisciplinaire HAL, est destinée au dépôt et à la diffusion de documents scientifiques de niveau recherche, publiés ou non, émanant des établissements d'enseignement et de recherche français ou étrangers, des laboratoires publics ou privés. 


\section{Eruption type probability and eruption source parameters at Cotopaxi and 2 Guagua Pichincha volcanoes (Ecuador) with uncertainty quantification}

A. Tadini ${ }^{1}$, O. Roche ${ }^{1}$, P. Samaniego ${ }^{1,2}$, N. Azzaoui ${ }^{3}$, A. Bevilacqua ${ }^{4}$, A. Guillin ${ }^{3}$, M. Gouhier ${ }^{1}$, B. Bernard $^{2}$, W. Aspinall ${ }^{5}$, S. Hidalgo ${ }^{2}$, J. Eychenne ${ }^{1}$, M. de' Michieli Vitturi ${ }^{4}$, A. Neri ${ }^{4}$, R. Cioni ${ }^{6}$, M. Pistolesi $^{7}$, E. Gaunt ${ }^{2}$, S. Vallejo ${ }^{2}$, M. Encalada ${ }^{2}$, H. Yepes ${ }^{2}$, A. Proaño ${ }^{2}$, M. Pique ${ }^{2,8}$

${ }^{1}$ Université Clermont Auvergne, Laboratoire Magmas et Volcans, CNRS, IRD, OPGC, 6 Avenue Blaise Pascal, 63178 Aubière, France.

${ }^{2}$ Escuela Politécnica Nacional, Instituto Geofísico, Ladrón de Guevara E11-253 y Andalucía, Quito, Ecuador.

${ }^{3}$ Université Clermont Auvergne, Laboratoire de Mathématiques Blaise Pascal, CNRS, 3 place Vasarely, 63178 Aubière, France.

${ }^{4}$ Istituto Nazionale di Geofisica e Vulcanologia, Sezione di Pisa, via Cesare Battisti 53, 56125 Pisa, Italy.

${ }^{5}$ School of Earth Sciences, University of Bristol, Wills Memorial Building, Queens Road, Bristol, BS8 1RJ, United Kingdom.

${ }^{6}$ Università degli studi di Firenze, Dipartimento di scienze della Terra, Via La Pira 4, 50121 Firenze, Italy.

${ }^{7}$ Università degli Studi di Pisa, Dipartimento di Scienze della Terra, Via Santa Maria 53, 56126 Pisa, Italy.

${ }^{8}$ University of Queensland, School of Earth and Environmental Sciences, St Lucia 4072, Brisbane, Australia

Corresponding author: Alessandro Tadini (Alessandro.TADINI@uca.fr)

\section{ORCID IDs}

Alessandro Tadini : 0000-0003-3603-0853

Olivier Roche: 0000-0002-6751-6904

Pablo Samaniego: 0000-0003-1169-3503

Andrea Bevilacqua : 0000-0002-0724-2593

Benjamin Bernard: 0000-0002-0333-5493

Willy Aspinall: 0000-0001-6014-6042

Silvana Hidalgo: 0000-0001-6386-9502

Julia Eychenne: 0000-0003-0344-6983

Mattia de' Michieli Vitturi: 0000-0002-6750-9245

Augusto Neri : 0000-0002-3536-3624

Raffaello Cioni : 0000-0002-2526-9095

Marco Pistolesi: 0000-0002-5096-3708

Elizabeth Gaunt: 0000-0002-1787-2062

Hugo Yepes: 0000-0001-6531-6311 


\title{
Acknowledgements
}

The authors are grateful to Geoffrey Wadge for useful comments and advices in the early stages of this project. Two anonymous reviewers are acknowledged for providing detailed comments that improved significantly the quality of this paper. We also thank the editorial handling of Andrea Cannata.

\section{Funding}

This research was financed by the French government IDEX-ISITE initiative 16-IDEX-0001 (CAP 20-25), the French Research Institute for Sustainable Development (IRD) in the context of the Laboratoire Mixte International "Séismes et Volcans dans les Andes du Nord", and the CNRS Tellus program. This work was also partly funded by the ClerVolc project - Program 1 "Detection and characterization of volcanic plumes and ash clouds" funded by the French government 'Laboratory of Excellence' initiative. This is ClerVolc contribution $\mathrm{n}^{\circ} 477$.

\section{Competing interests}

The authors have no competing interests to declare.

\section{Code and data availability}

The EXCALIBUR code used to process the data is downloadable at the following address http://www.lighttwist.net/wp/excalibur. Other scripts to process the data are available under request - i.e. ERF scores, logic tree probability calculations, Monte Carlo sampling. The raw data used in this study are available as supplementary material and in a repository from the Figshare community with the following DOI 10.6084/m9.figshare.13148753.

\section{Authors' contributions}

A. Tadini: Conceptualization, Formal Analysis, Investigation, Data Curation, Writing - Original Draft, Writing Review and Editing, Visualization; O. Roche: Conceptualization, Investigation, Writing - Review and Editing, Project administration, Funding acquisition; P. Samaniego: Conceptualization, Investigation, Resources, Writing - Review and Editing, Visualization, Supervision; N. Azzaoui: Conceptualization, Investigation, Writing - Review and Editing, Visualization, Supervision; A. Bevilacqua: Formal Analysis, Software, Investigation, Data Curation, Writing - Review and Editing, Visualization; A. Guillin: Conceptualization, Investigation, Writing - Review and Editing, Project Administration, Supervision, Funding Acquisition; M. Gouhier: Conceptualization, Investigation, Writing - Reviewing and Editing, Supervision; B. Bernard: Investigation, Resources, Writing - Review and Editing, Funding Acquisition; W. Aspinall: Methodology, Software, Investigation, Writing - Review and Editing, Visualization; S. Hidalgo: Investigation, Resources, Writing - Review and Editing, Visualization; M. de'Michieli Vitturi, A. Neri, R. Cioni, M. Pistolesi, E. Gaunt, S. Vallejo, M. Encalada, H. Yepes, A. Proaño, M. Pique: Investigation, Writing - Review and Editing.

\begin{abstract}
Future occurrence of explosive eruptive activity at Cotopaxi and Guagua Pichincha volcanoes, Ecuador, is assessed probabilistically, utilizing expert elicitation. Eight eruption types were considered for each volcano. Type event probabilities were evaluated for the next eruption at each volcano and for at least one of each type within the next 100 years. For each type, we elicited relevant eruption source parameters (duration, average plume height and total tephra mass). We investigated the robustness of these elicited evaluations by deriving probability uncertainties using three expert scoring methods. For Cotopaxi, we considered both rhyolitic and andesitic magmas. Elicitation findings indicate that the most probable next eruption type is an andesitic hydrovolcanic/ash-emission ( 26-44\% median probability), which has also the highest median probability of recurring over the next 100 years. However, for the next eruption at Cotopaxi, the average joint probabilities for sub-Plinian or Plinian type eruption is of order $30-40 \%$ - a significant chance of a violent explosive event. It is inferred that any Cotopaxi rhyolitic eruption could involve a longer duration and greater erupted mass than an andesitic event, likely producing a prolonged emergency. For Guagua Pichincha, future eruption types are expected to be andesitic/dacitic, and a vulcanian event is judged most probable for the next eruption (median probability $\sim 40-55 \%$ ); this type is expected to be most frequent over the next 100 years, too. However, there is a substantial probability (possibly $>40 \%$ in average) that the next eruption could be sub-Plinian or Plinian, with all that implies for hazard levels.
\end{abstract}

Keywords: Cotopaxi volcano, Guagua Pichincha volcano, volcanic hazard, elicitation, uncertainty quantification 


\section{Introduction}

The future behavior of a volcano is a matter of central concern for volcanic hazard and risk assessment. The estimation of probability of eruption scenarios depends on two factors: i) the temporal probability of an eruption and ii) the conditional probability of a particular eruptive scenario given that an eruption occurs (Connor et al. 2015; Poland and Anderson 2020). In this study we will mostly focus on the latter. These probabilities serve as a basis for scenario and evacuation plan definition, long-term urban planning and risk mitigation. Additionally, the estimate of the uncertainty ranges for eruption source parameters (ESPs) is a key aspect for the development of probabilistic hazard maps, which mainly rely on numerical models (e.g., Costa et al. 2009; Bonasia et al. 2011; Biass et al. 2014; Vázquez et al. 2019). To the extent that the past eruptive history of a volcano is known and rigorously analysed, both aspects can be addressed with some measure of accuracy provided associated uncertainties are accounted for.

While the recurrence probabilities of different volcanic eruptions can be assessed through the development of temporal models (e.g., Mulargia et al. 1985; De la Cruz-Reyna 1993; Bebbington and Cronin 2011; Bevilacqua et al. 2016), conditional probabilities of eruption type are usually described using either Bayesian belief networks (e.g., Aspinall and Woo 2014; Hincks et al. 2014; Christophersen et al. 2018) or event trees (e.g., Newhall and Hoblitt 2002; Martí et al. 2008; Neri et al. 2008; Tierz et al. 2020). Incompleteness and uncertainty of the eruptive records affect temporal modelling, and difficulties in incorporating monitoring signals are challenging issues that have been tackled using several approaches, including hidden Markov models (Aspinall et al. 2006; Wang and Bebbington 2012; Bevilacqua et al. 2020a), variably combined statistical models (Marzocchi and Bebbington 2012; Runge et al. 2014; Bevilacqua et al. 2018) or the failure forecast method (Voight 1988; Robertson and Kilburn 2016; Kilburn 2018; Bevilacqua et al. 2019; Bevilacqua et al. 2020b; Bevilacqua et al. 2020c).

Each eruption of a volcano is characterized by specific ESPs whose range of variation, especially if they are factors to be applied in probabilistic studies, can be estimated from field data (e.g. Macedonio et al. 2016; Parra et al. 2016; Biass et al. 2017) or derived from analogue volcanoes and/or general distribution of ESPs (e.g. Mastin et al. 2009; Sheldrake 2014; Sheldrake et al. 2016; Gouhier et al. 2019). While it is straightforward to define a uniform probability distribution between two end-member values for each ESP, this approach can entail potential loss of information that might be present in data and records, which may provide an objective basis for a more informative uncertainty distribution function. To offset such limitations, it can be useful to adopt structured expert judgment techniques (Aspinall 2006; Aspinall and Cooke 2013) to explicitly derive a unique credible uncertainty range and a corresponding elemental probability distribution for each of the investigated variables through weighted pooling of a group of experts' uncertainty distributions. This approach has been adopted both for describing the future behavior of a volcano (Martí et al. 2008; Neri et al. 2008) and also for determining some ESPs (Bebbington et al. 2018; Christophersen et al. 2018; Aspinall et al. 2019).

The aim of this paper is to report assessed conditional probabilities of experiencing different eruption types (and their main ESPs) - conditional on the future occurrence of an eruption - at Cotopaxi and Guagua Pichincha volcanoes, two of the most active and hazardous volcanoes in Ecuador. At both volcanoes, the spectrum and magnitudes of potential eruptive types can range from minor but long-lasting ash emissions or vulcanian to Plinian eruptions, and their relative probabilities of occurrence must be assessed on a coherent basis to obtain self-consistent volcanic hazards assessments and to support reasoned decision-making. In this paper we are focusing on explosive eruptions due to the greater hazard that they pose in terms of the large areas potentially affected by tephra dispersal.

Here, these challenges are addressed with an established expert elicitation methodology for the formal numerical quantification of uncertainties, the results of which can inform event trees for the two volcanoes. These findings contribute to a long-term project aimed at developing new probabilistic tephra hazard maps for Cotopaxi and Guagua Pichincha volcanoes. In this project, a new procedure for quantifying relevant uncertainties in a tephra transport and dispersal model has been recently proposed (Tadini et al. 2020). Here, the quantification of other, related uncertainties (both epistemic and aleatoric, Tadini et al. 2017b) represents a further advance towards a fully probabilistic volcanic hazard assessment approach that will enable uncertainties to be explicitly accounted for producing the resulting tephra hazard maps.

For Cotopaxi, two studies have been recently published about tephra fallout hazard and risk assessment. Biass and Bonadonna (2013) developed semi-probabilistic and probabilistic hazard maps and curves by using the TEPHRA2 model (Bonadonna et al. 2005) and considering eruptive scenarios with VEI $\geq 3$. Moreover, using data from the global volcanism program database, the authors calculated the probability of occurrence of an eruption of VEI $\geq 3$ for the next $10(36.2 \%)$ and 100 (98.9\%) years. Additionally, Biass et al. (2013) performed a risk assessment for eruptions with VEI $\geq 4$, highlighting the possible collapse due to ash loading of several thousands of houses in the proximity of the volcano, the destruction of agriculture and the possible disruption of major roads. The potential high impact of tephra fallout on the new Quito International airport, considering Cotopaxi among other volcanoes, has been addressed by Volentik and Houghton (2015). For Guagua Pichincha, 
they highlighted that the small-size AD 1999 eruption (see section 2.2) resulted in huge economic losses to the tourism and agricultural sectors. In order to consider further the impact that an eruption of even moderate size could have on aviation, the definitions of eruptive scenarios and recurrence probabilities for Cotopaxi and Guagua Pichincha are therefore crucial.

Before addressing these and other hazard-related assessment issues, we provide first a general overview on Cotopaxi and Guagua Pichincha volcanoes (section 2) and on expert elicitation techniques (section 3, with details in the Appendix). Then, we present a detailed analysis of our findings (section 4), with further considerations about the procedure and prospective implications for hazard levels at Cotopaxi and Guagua Pichincha (section 5).

\section{Volcanic context}

Cotopaxi and Guagua Pichincha volcanoes (Fig. 1) are located, respectively, $\sim 60 \mathrm{~km}$ South and $\sim 10 \mathrm{~km}$ West of Quito, Ecuador's capital city. About 150,000 and 2 million inhabitants live within $30 \mathrm{~km}$ of Cotopaxi and Guagua Pichincha volcanoes (Global Volcanism Program 2013), respectively.

\subsection{Cotopaxi volcano}

Cotopaxi is a 5,897 $\mathrm{m}$ high active volcano located on the Eastern Cordillera. According to Hall and Mothes (2008), the eruptive history of Cotopaxi volcano started roughly $0.5 \mathrm{Ma}$, and it is characterized by a bimodal volcanism involving rhyolitic (70-75 wt.\% $\left.\mathrm{SiO}_{2}\right)$ and andesitic (56-62 wt.\% $\left.\mathrm{SiO}_{2}\right)$ magmas. The same authors calculated a total erupted DRE volume during the last $0.5 \mathrm{Ma}$ of $28.54 \mathrm{~km}^{3}$ and they gave a detailed evolution of total erupted volume with time (Fig. 20 of Hall and Mothes 2008). Cotopaxi activity was characterized during its early stages by a series of large eruptions involving magmas of rhyolitic composition lasting $\sim 0.1 \mathrm{Ma}$ (Barrancas series, Hall and Mothes 2008). After a long repose period of $\sim 0.4 \mathrm{Ma}$, except for a short andesitic activity at around 0.45 Ma BP (Rio Pita Series), the volcanic activity resumed with other five eruptive episodes (F series, Hall and Mothes 2008). Such series (9.6-5.5 ka BP) were mainly rhyolitic in composition, but andesitic magmas erupted repeatedly, a fact that allowed Hall and Mothes (2008) to infer that andesitic magma already existed or was rising from depth. The subsequent Colorado Canyon series ( 4.5 ka) involved rhyolitic magmas and included a sector collapse on the NE side of Cotopaxi (Smyth and Clapperton 1986; Mothes et al. 1998; Vezzoli et al. 2017). From the end of the Colorado Canyon episode until the present day, magmas erupted from Cotopaxi were almost all andesitic in composition, except one rhyolitic ash level dated at $2.1 \mathrm{ka}$ (Barberi et al. 1995; Hall and Mothes 2008). For the period 4-1 ka, Hall and Mothes (2008) reported a total of 25 eruptions (18 of which were considered as Plinian events with VEI 4). The subsequent period represented the historical activity of Cotopaxi volcano, which lasted from AD 1532-34 up to AD 1880, with minor activity occurring in the $20^{\text {th }}$ century (Pistolesi et al. 2011) and a full resumption of activity with the AD 2015 eruption (Bernard et al. 2016; Hidalgo et al. 2018). The period 1532-1880 (total erupted volume of 2.14 DRE km3, Hall and Mothes 2008) was studied in detail by Pistolesi et al. (2011) who identified 13 layers/eruptions grouped in 6 sets. Within the last 1 $\mathrm{ky}$, all the eruptions involved andesitic magmas and there have been both violent Strombolian VEI 2-3 (AD 1853), sub-Plinian VEI 3-4 (AD 1877 and XVIII century) and Plinian VEI 4-5 (Layer 3 - 820 \pm 80 years BP; Layer 5 - 1180 80 years BP, Biass and Bonadonna 2011; Tsunematsu and Bonadonna 2015) eruptions. After small-scale (VEI 1-2) explosions reported in the years 1904 and 1942 (Pistolesi et al. 2011), Cotopaxi reawakened in AD 2015 resulting in a $\sim 3$ months long eruption, characterized by an opening hydrovolcanic (or phreatomagmatic) phase (Bernard et al. 2016) followed by a long-lasting ash emission (Gaunt et al. 2016; Hidalgo et al. 2018). Table 1 summarizes the main typologies of explosive eruptions of Cotopaxi considered in the production of the logic trees in the following sections. We highlight that this table does not record completely the eruptive history of the volcano, but it has been used as a basis to describe the spectrum of explosive activity at Cotopaxi volcano. Despite this explosive activity is preponderant, effusive activity at Cotopaxi is also documented (Hall and Mothes 2008; Pistolesi et al. 2011), although it is often linked to other explosive eruptions (e.g. AD 1853; Pistolesi et al. 2011). For this reason, a separate category of "effusive eruption" has not been considered in our study.

\subsection{Guagua Pichincha volcano}

The Pichincha volcanic complex is composed of two distinct edifices sitting atop the El Cinto lavas (0.1-1.1 Ma, Robin et al. 2010), the older Rucu Pichincha (4,694 m a.s.1.) and the younger Guagua Pichincha (4,784 m a.s.1.). The magmatic composition of the erupted products of both the Rucu and Guagua Pichincha is andesitic to dacitic (55-66 wt.\% $\mathrm{SiO}_{2}$ ), while the eruptive history of the former spans the period $0.85 \mathrm{Ma}-0.15 \mathrm{Ma}$ and the second began to erupt at around $60 \mathrm{ka}$ (Robin et al. 2010). The development of the Guagua Pichincha volcano 
involved two major sector collapses (at $\sim 11 \mathrm{ka}$ and $\sim 4 \mathrm{ka}$ ), which were linked to changes in the erupted rock chemistry due to the arrival of new magma batches (Robin et al. 2010). The last "Toaza" sector collapse occurred around $4 \mathrm{ka}$ and the volcanic activity resumed roughly $2 \mathrm{ka}$ with the development of a new summit dome (the "Cristal dome"). This dome experienced phases of growth /collapse and related block-and-ash flows and blasts (Robin et al. 2008). Due to the above-mentioned changes in rock chemistry that occurred after the "Toaza" sector collapse, we will focus on the eruptive history after $4 \mathrm{ka}$. The volcanic activity of the last 2000 years has been the topic of several studies aimed at better characterizing the stratigraphy, the chronology of the eruptions and the volcanic hazard (Geotermica Italiana 1989; Barberi et al. 1992; Robin et al. 2008). This period involved three major eruptive cycles (I century, X century, Historic) separated by repose periods of the order of 300-500 years. Each cycle was initiated with phases of dome emplacement and explosive episodes, and involved a final Plinian-like eruption (Robin et al. 2008). As a reference, the Historic cycle involved at least 3 eruptive explosive episodes (testified by historical accounts, Wolf 1904) in AD 1566, 1575, and 1582, with ash fallout in Quito and pyroclastic density currents at the west side of the volcano. The Plinian-like eruption of AD 1660 closed this cycle (Robin et al. 2008). After the Historic cycle, phreatic explosions occurred at Guagua Pichincha in the XIX century and became more frequent (and correlated with seasonal rain) in the years 1981-1998 (Garcia-Aristizabal et al. 2007). Particularly, in AD 1998 there was a sudden increase of the phreatic activity, which presaged the first dome-forming eruption of the 1999-2001 cycle. During this cycle, 8 dome-forming eruptions (each of them followed by the dismantling of the newly formed dome) took place, and several Vulcanian eruptions (including the AD 1999, the largest of the cycle) destroyed the first domes (GarciaAristizabal et al. 2007; Wright et al. 2007). The similarities (in terms of eruptive styles) between the eruptive cycle of 1999-2001 with the early stages of the Historic and X century cycles, permitted Robin et al. (2008) to infer that the 1999-2001 cycle might be the first step of a mid-term evolution that will eventually result in a Plinian-like eruption like that of AD 1660. Table 2 summarizes the main typologies of explosive eruptions of Guagua Pichincha volcano considered in the production of the logic trees in the following sections. Also in this case we report in this table just a selection of eruptions to define the typologies for the logic trees in Fig. 2. For Guagua Pichincha, differently from Cotopaxi, the effusive dome-forming activity is more significant, but it is not considered in our study due to the specific focus on explosive activity.

\section{Methods}

\subsection{Elicitation}

Our study involved all the participants in the author list, representing different levels of experience and a variety of scientific backgrounds. These specialists all have at least a basic background in volcanology, and the majority has undertaken detailed work on Cotopaxi or Guagua Pichincha volcanoes, or both. The elicitation (see Appendix A for details) started with a seed questionnaire (for determining experts' weighting) composed of 15 factual questions about Ecuadorian/South American volcanism and numerical modelling of volcanic ash (without considering monitoring data). Participants were not expected to know precisely the quantitative values of the questions but they were expected to be able to provide credible intervals that captured the 'true' values for at least some of the questions. Thus, for each question, participants were asked to provide their immediate uncertainty judgments by suggesting their own $5^{\text {th }}$ percentile, $50^{\text {th }}$ percentile (median), and $95^{\text {th }}$ percentile estimates of the - for them, unknown - values in question. To avoid influencing and group-thinking, each person responded individually and confidentially to the elicitation facilitator. The seed questionnaire used in this session is provided as Online Resource 1.

These questions were processed by applying three well-established scoring methods to calculate each expert's calibration and informativeness scores (details are available in the Appendix A). The methods are Cooke's Classical Model (CM - Cooke 1991; Aspinall 2006), the Expected Relative Frequency method (ERF Flandoli et al. 2011; Bevilacqua 2016), and the Equal Weights (EW) rule (Bevilacqua 2016). The purpose of using three scoring methods is twofold. First, it underlines the robustness of the outcomes where CM, ERF and EW methods have similar or coincident trends. Second, it can help identifying if two or more different "school of thoughts" exist among the experts on any item of interest. A discussion about the outcomes of the three scoring methods (CM, ERF and EW) is given in Flandoli et al. (2011) and reported in Appendix A.

The calibration and informativeness scores are thus used to define each expert's weight to be applied when considering the judgments on the 'target item' questions, i.e. the variables of interest. In this form, target item responses are pooled together with the experts' weights to produce a group synthesized uncertainty distribution, often called a 'decision maker' solution (DM). Where necessary for clarity in the paper, we will also call "decision-taker" the actual person in charge of taking decisions. As with the calibration questions, for the target questions the experts were asked again to provide their judgments and associated uncertainties as $5^{\text {th }}$ percentile, $50^{\text {th }}$ percentile (median), and $95^{\text {th }}$ percentile values. The advantage of this approach (especially for ESPs) is that 
it is possible to obtain elemental uncertainty distribution markers for each variable and not just simple variation ranges between a maximum and minimum value.

The purpose of the target questionnaires about Cotopaxi and Guagua Pichincha was twofold. Firstly, it aimed at assessing the relative conditional probability of different types of volcanic activity (see Appendix A for the definition of "eruption" used in this study) and associated magma composition (the latter for Cotopaxi only) in a specific temporal frame. More specifically, such questions were considered in two frameworks, namely the "next eruption" and the "next 100 years" cases, the former being the most explosive phase of the eruption considered and the latter being the probability of having at least one eruption type/magma composition within the next 100 years. We introduced this differentiation because the 'next eruption' case is surely the most relevant for short to medium-term hazard assessment, but that would have to be updated with new expert judgments and re-evaluated after a new eruption would occur. On the contrary, the 'next 100 years' case aims at providing a longer time frame and it facilitated the experts in focusing on single eruptions in such time frame. These two sets of questions are denoted, respectively, with the abbreviations "NE" and "N100" in the following sections. An important consequence of this subdivision is that, while the NE case contains mutually exclusive events summing to $100 \%$, the N100 case does not exclude the possibility of having eruptions of different type as subsequent events.

Figure 2 displays the logic tree for Cotopaxi and Guagua Pichincha, whose branches represent the abovementioned target questions. With these event trees we aim at quantifying the conditional probability of explosive eruptions, as they pose a higher number of hazards than effusive ones. The latter should be considered as part of the "Other eruption" types, which include both effusive events and other events not recorded in the stratigraphy of the volcano nor in the historical observations. However, we do not exclude that for some other type of eruptions (for example the "Violent Strombolian" or "Vulcanian" for Cotopaxi and Guagua Pichincha, respectively) there may be some lava outpourings associated to the eruption scenario.

The probability of occurrence of the various types of volcanic activity could be also inferred from the available information on past recurrence rates in the global datasets of volcanic eruptions (Smithsonian GVP, LaMEVE). Statistical modeling of global VEI-frequency distributions using extreme value methods (Coles and Sparks 2006; Deligne et al. 2010; Furlan 2010; Rougier et al. 2016; Papale 2018), or through comparison of the global record with the well-characterized record in Japan (Kiyosugi et al. 2015) provide insight into possible corrected distributions, but regional differences make the global record difficult to apply to single volcanoes (Rougier et al. 2018). Much remains to be learned about global trends in volcanic explosivity, and uncertainty is very high (Deligne et al. 2017). In particular, there are problems with calculation of VEI distribution through time, including under-recording of small magnitude events backward through time, and over-recording of VEI 2 events by the Smithsonian GVP. For these latter reasons, our expert judgment approach does not rely on such global data.

The target questionnaires addressed also the uncertainty range of some key ESPs (eruption duration in minutes, total mass of the tephra fallout deposit in $10^{9} \mathrm{~kg}$ and average plume height in $\mathrm{km}$ ) for the different types of eruptions, according their importance for volcanic hazard assessment and numerical modelling, especially concerning tephra fallout.

We have not directly elicited some other parameters important for tephra fallout hazard assessment and numerical modeling, such as total grain-size distribution, particle densities, particle shape factors, and initial volatile content of magma. For these parameters we have considered that either their uncertainty has been already adequately modeled without using expert judgment techniques (e.g. total grain-size distribution, Costa et al. 2016) or that their uncertainty range might be better described by a linear variation between two endmembers. For example, in this latter case, we found good constraints for both Cotopaxi and Guagua Pichincha volcanoes for initial water mass fractions (Wright et al. 2007; Samaniego et al. 2010; Andújar et al. 2017; Martel et al. 2018), particle densities (Bonadonna and Phillips 2003; Pistolesi et al. 2011) and particle shape factors (Riley et al. 2003).

\section{Results}

\subsection{Eruption probabilities and ESPS}

In this section, we report the results of the elicitation, subdivided in graphical outputs (Figs. 3 and 4) and triplets of values (Tables 3-6). The graphical outputs show the probability density functions of the DM resulting from the application of a Gaussian kernel density estimator (Silverman 1986; Connor and Connor 2009; Tadini et al. 2017a) to the weighted combination of the experts' probability distribution judgments. This means that we extracted a sufficient number of samples $\left(10^{5}\right)$ of expert answers, a number selected by iteration to assure a robust convergence of the kernel density estimator. This differs from the original formulation of the ERF method (Flandoli et al. 2011), in which the DM resulted from the linear combination of the quantiles of the experts' probability distributions. In particular, we abandoned the quantile combination approach because it would have 
averaged the median values of different experts instead of producing multimodal distributions (e.g. Bevilacqua, 2016). More specifically, when calculating the DMs, we performed a linear combination (i.e. a probability mixture) of maximum entropy distributions, i.e. uniformly distributed between the elicited percentiles (Cooke, 1991) in all the three methods. We remark that in the calculation of the ERF scores on the 'seed questionnaire' we adopted triangular probability distributions, while for the definition of the DM on the 'target questionnaire' we used maximum entropy distributions. This choice enabled a better comparison of ERF with the CM and EW, but it differs from Bevilacqua et al. (2015) and Tadini et al. (2017a).

We also highlight that multi- or bimodality in the resulting probability density functions is a consequence of the different modes expressed by different experts, while the full uncertainty range (in Tables 3-6) is obtained from the envelope of all experts and their judgments. The triplets of values in the tables therefore summarize the DM's probability distribution with three percentiles $\left(5^{\text {th }}, 50^{\text {th }}\right.$ and $\left.95^{\text {th }}\right)$. These triplets have been recalculated from the original elicitation data in order to have conditional probabilities with respect to rhyolitic or andesitic magmas, respectively. Given the large amount of elicitation data, we only report in the main text the graphical outputs of the conditional probabilities. Those of the ESPs are provided in the supplementary material (Online resource 2), together with the experts' weights (Online resource 3).

For Cotopaxi volcano, the results of the elicitation are provided in Figure 3, Table 3 (conditional probabilities) and Table 5 (ESPs) for the CM, ERF and EW methods. Similarly, for Guagua Pichincha volcano, results are provided in Figure 4, Table 4 (conditional probabilities) and Table 6 (ESPs). Eruption durations are given in minutes. We highlight two general observations. Firstly, for all the distributions, in our formulation, the ERF answers are generally between the CM and the EW ones, and they are significantly closer to the latter; this is particularly evident by comparing the probability density functions (see Figs. 3 and 4). Secondly, if the uncertainty range of the distributions is considered (i.e. the $5^{\text {th }}$ and $95^{\text {th }}$ percentiles in Tables $3,4,5$ and 6 ), the $\mathrm{CM}$ distributions are in general more informative, that is, they are more focused (although slightly) around the $50^{\text {th }}$ percentile.

For Cotopaxi, considering the CM method, we evaluated that the three percentiles $\left(5^{\text {th }}, 50^{\text {th }}, 95^{\text {th }}\right)$ of the conditional probability that the next eruption (NE case) will involve rhyolitic magma are $[0.4,8.4,39] \%$, with a mean value of $13 \%$. The ERF and EW methods produced median values of $11-12 \%$ and mean values of 16 $20 \%$. In contrast, the conditional probability of having eruptions involving andesitic magmas is $[61,92,>99] \%$, with a mean value of $87 \%$ considering the CM method. In these two cases, the corresponding probability density functions for all the scoring methods (Fig. 3) show a clear unimodality, with the CM scoring method having a slightly higher peak with respect to ERF and EW. Instead, in the rhyolitic case, the probability density functions for the sub-Plinian and Plinian eruptions are markedly multimodal for all the scoring methods, with the ERF and EW solutions having similar trends. The different probability peaks are illustrated in Figure 3. In the andesitic case, the hydrovolcanic/continuous ash emission (like AD 2015) has been evaluated the most probable next eruption (NE case). There are, however, some differences among the scoring methods, with the ERF and the EW having noticeably lower median values (28\% and $26 \%$ ) than the CM solution (44\%) - (mean values of $28 \%$, $27 \%$, and $44 \%$ respectively). Similar inferences can be made for the corresponding probabilities in the N100 case at Cotopaxi, with probability values that are generally higher because we did not assume mutually exclusive events. For example, the median probability of at least one hydrovolcanic/continuous ash emission in the next 100 years is $43-55 \%$, depending on the method (mean values in $43-51 \%$ ). We remark that the abovementioned cases for the NE case, where distributions show bi- or multimodality, have bi- or multimodality also in the N100 case, with even more fluctuations (see Fig. 3).

For the NE case at Guagua Pichincha, despite the fewer number of eruption types (and just one magma composition in consideration), there is one eruption type (i.e. Vulcanian - see Table 4 and Fig. 4) for which there are relatively large differences among the scoring methods. A Vulcanian eruption has been considered the most probable event, but the median values are 55\% for the CM, $45 \%$ for the ERF and $40 \%$ for the EW (mean values of $51 \%, 44 \%$, and $40 \%$ ). More details about the other percentiles can be found in Table 4 and in Appendix B. The differences among the three scoring methods is, in contrast, lower for the other cases (sub-Plinian, Plinian and other - Fig. 4). We remark also that the median conditional probability for "Other" eruption types has been evaluated with a median probability ranging from $7.5 \%$ up to $11 \%$, depending on the method selected (mean values of $13 \%$ up to $18 \%$ ). For the N100 case, considerations similar to those for Cotopaxi can be made as there are larger fluctuations in the probability density functions (Fig. 4), describing bi- or multimodal distributions for all cases (except for the "Other eruption" case).

Considering parameter uncertainty ranges for both Cotopaxi and Guagua Pichincha (Tables 5 and 6), the average plume height is the parameter for which the differences among the three scoring methods are lowest (see also Online resource 2). In general, however, differences between the median values of the other two parameters (total mass and total duration) for the three scoring methods are generally low. 
Three sensitivity assessments of the outcomes of the CM analysis were performed with respect to experts' career ages, main scientific expertise and geographic affiliation at the time of the elicitation. The goal was to highlight possible trends that might have been influenced by the different backgrounds/experiences of the various experts involved. It is important to highlight that, with respect to any of the sub-groups, the CM outcomes are not a measure of the average knowledge of the participants of a sub-group about the volcanological problem as a whole, but rather a measure of the participants' abilities to judge volcanological quantitative uncertainties. Weights assigned with the EW rule are reported as well in order to highlight the overall agreement or disagreement among experts within different sub-groups. Six sub-groups were analyzed as paired comparisons, which are: Senior researchers vs. Early-career researchers (A1 vs. A2 - 14 and 6 experts respectively); Geologists vs. Mathematicians-Modelers (B1 vs. B2 - 9 and 11 experts respectively) and Clermont-Ferrand vs. Quito (C1 vs. C2 - 12 and 8 experts respectively). The latter group refers to the location of the experts at the time of the elicitation, which was performed in one single session, but with experts remotely connected from the two different localities. Senior researchers were those with $>10$ years of academic career after obtaining the PhD. The pairs of sub-groups (e.g. A1/A2 vs. B1/B2) are significantly different and not correlated by construction. Therefore, the elicitation responses have been analyzed in order to highlight possible biases given by the fact that, within the sub-group $\mathrm{C} 1$, some experts have not worked on the studied volcanoes as deeply as those of sub-group C2. The complete dataset for this analysis is available in Online resources 6 and 7 .

To compare the outputs of the elicitation considering the whole group or different sub-groups, we have analyzed the outputs in the two tables in Supporting Information by performing principal component analysis (PCA) of the data (Wold et al. 1987; Chiasera and Cortés 2011). This procedure allowed us to obtain the PCA eigenvector and its eigenvalues (described by two dimensions' $\mathrm{x}$ and $\mathrm{y}$ referred here as Dim1 and Dim2), which indicate the direction of maximum spread of multivariate data. As shown in Figure 5, we used CM data to create sub-plots with normalized eigenvectors for two sub-groups (A1 vs. A2, B1 vs. B2, C1 vs. C2), along with that of the whole group (All). This approach allows us to discuss, for each sub-plot, how similar the absolute values, obtained considering the group as a whole (All), are to one sub-group or another.

We remark that in Fig. 5 the direction of each arrow could vary as a function of the uncertainty spread of the DM solution for each subgroup, and that if the arrow of one subgroup is closer to the reference "All" arrow, this indicates that the two are more closely similar to each other than the DM solution of the other subgroup. Conversely, equidistance of the "All" arrow from both subgroups indicates that the "All" DM is balanced between them.

Results displayed in Figure 5 highlight the following trends: i) eigenvectors of the sub-groups for Cotopaxi (Fig. 5a) tend to have an higher spread, within each sub-plot, than those of Guagua Pichincha (Fig. 5b), as indicated by the higher percentages of Dim2 in all the Cotopaxi sub-plots; ii) eigenvectors of ESPs tend to be more closely related to their corresponding "All" solutions than those of conditional probabilities for both volcanoes, with the exception of sub-groups A1 vs. A2 (Senior researchers vs. Early-career researchers); iii) for both volcanoes, the eigenvector representing the whole group ("All") tends to be placed in the middle of the sector defined by the eigenvectors C1 vs. C2 (Clermont-Ferrand vs. Quito), while that for A1 vs. A2 (Senior researchers vs. Early-career researchers) tends to be closer to the eigenvector A1 and that for B1 vs. B2 (Geologists vs. Mathematicians-Modelers) tends to be consistently closer to the eigenvector B1.

These analysis findings, and their possible implications, are discussed in more detail in Section 5 below.

\section{Discussion}

\subsection{Expert scoring methods and sensitivity analyses}

In this paper we provide a detailed method to analyze an elicitation that addressed future eruption types and their likelihoods for Cotopaxi and Guagua Pichincha volcanoes. Our approach involves comparisons of probability density functions from the experts' judgments about eruption probabilities and eruptive parameters (Tables 3 and 4, Figs. 3 and 4 and Online resource 2). In earlier studies that involved comparison between different scoring methods (for Campi Flegrei/Vesuvius volcanoes), consistency of elicitation outputs suggested that the findings were similar among them and robust (Bevilacqua et al. 2015; Tadini et al. 2017a). In this new study we find the same trend of consistency for the majority of the questions, suggesting again the general robustness of elicitation outputs. In just two cases a slightly greater intrinsic uncertainty on some of the issues elicited demonstrated that different results could be obtained when scoring the experts in a different way (e.g. "Hydrovolcanic/Ash emission eruption - NE" for Cotopaxi, Fig. 3; "Vulcanian eruption - NE" for Guagua Pichincha - Fig. 4). These differences highlight a general uncertainty in characterizing both the occurrence and the ESPs of these types of small magnitude eruptions, for which there is not an extended worldwide database and which might have been more frequent than those recorded in the stratigraphic record. In addition, it is also more 
difficult to place these eruption types within well-known eruption categories, which are often mostly based on larger magnitude events (see for example Mastin et al. 2009). More studies are therefore needed in this sense. It is also important to remind that in this study we have used a classification scheme for eruptions that differs from the classical VEI scale: this might also explain some differences observed in experts' assessments, which might give different VEI scale representations within our classes._Furthermore, while not being highly relevant, the highlighted differences among scoring methods could be taken into consideration if these particular outputs were to be used for any hazard or risk decision purposes, and in general a choice should be made about which solution to adopt: that of the CM, the ERF or the EW method. Notwithstanding the CM scoring method has been used traditionally in many studies, both in volcanology and other fields (Aspinall 2006), the choice about which outcome to consider is ultimately a responsibility of the (human) decision-taker. With respect to this latter issue, it is worth keeping in mind that the CM is a "selective" scoring method (due to the properties of the "calibration" score, see Appendix A) and is therefore efficient in selecting, from a potentially large group of experts, those that are statistically more accurate in constraining uncertainties. On the other hand, a less "selective" scoring method, like ERF, gave results similar to that of the EW method, if compared to the CM. This similarity was enhanced by having used the same DMs definition algorithm in all the methods, except for the difference in the experts' scores. While in most of the situations performing this selection using the CM scoring method is justified, in other contexts it can be important for the human decision-taker to consider pooling outcomes derived from the judgments of the group as a whole (i.e. by considering counterpart EW or ERF DM solutions). In summary, comparing the outcomes of different scoring methods allows highlighting differences in scientific basis that might influence expert forecasts. Such differences are related to variation in assessment of incompleteness of the eruptive record or variations in the different models (scientific, conceptual, or mechanical) assumed by the experts for providing their judgments. The investigation of the motivations behind the differences between the experts responses is not the aim of the elicitation session (see Appendix A; Cooke, 1991).

To provide more cogency for the choice of one scoring method over another, or to select estimations obtained from one specific sub-group of experts, we have also performed PCA analysis to explore the relative information contents of each option. The trends discussed in section 4.2 highlight primarily that, for the two volcanoes, the experts' judgments are slightly less homogeneous for Cotopaxi than for Guagua Pichincha, as indicated by the higher Dim2 percentages in all the sub-plots of Figure 5a with respect to those of Figure $5 \mathrm{~b}$. Very likely, this observation could be correlated with the higher complexity of the logic tree of Figure 3 (Cotopaxi) versus Figure 4 (Guagua Pichincha). In other words, the greater number of eruption types and the potential involvement of two alternative different magmas complicates matters for Cotopaxi compared with Guagua Pichincha.

Moreover, the ESP PCA sub-plots for Cotopaxi have a higher Dim2 value than that of Guagua Pichincha. This could be linked to the greater difficulty in constraining uncertainty ranges for the ESPs of the small magnitude eruptions as the hydrovolcanic/continuous ash emission (Bernard et al. 2016) and Violent Strombolian type eruptions. However, for both volcanoes (especially for the sub-groups B1 vs. B2, and for C1 vs. C2) Dim2 is lower for the sub-plots with ESPs than for the corresponding sub-plots for conditional probabilities, suggesting a greater uniformity of judgments among sub-groups for ESPs than for conditional probabilities.

Finally, an important aspect is linked to the orientation of the eigenvector of the whole group (All) with respect to those of the sub-groups. As highlighted in section 4.2, the eigenvector "All" is found to be located in the middle of the sector defined by the alternate eigenvectors $\mathrm{C} 1$ vs. $\mathrm{C} 2$, for both Cotopaxi and Guagua Pichincha. This observation indicates that the final absolute values are equally distant (and therefore balanced) between the judgments of the two sub-groups with different institutional locations (i.e. Clermont-Ferrand and Quito). However, for the sub-plots A1 vs. A2 and for B1 vs. B2 in Figure 5, the "All" eigenvectors are generally closer to A1 (Senior Researchers), and more toward B1 (Geologists) in the latter. These findings suggest that institutional affiliation did not influence the DM as much as age and background.

\subsection{Implications for hazard assessment and numerical modelling}

The results of the elicitation have implications for hazard assessment, both for conditional probabilities and the related eruption parameters. Moreover, it is interesting to consider which questions (and related scenarios) are affected by greater uncertainties, both from the point of view of epistemic uncertainty on eruption types conditional probability ("Other eruption" cases) and intra-question uncertainty (i.e. the credible interval distance between the $5^{\text {th }}$ and the $95^{\text {th }}$ percentiles within each question). The two timeframes chosen (i.e. next eruption and next 100 years) enable us also to analyze two different perspectives for the volcanoes. Specifically, in our opinion, the probability density functions of the NE case could be used for preparing a probabilistic hazard map (or to define emergency plans) for immediate use. This could be accomplished either by considering single eruptions, or by combining the different maps obtained for different eruption types, weighted by the appropriate probability of occurrence (Sandri et al. 2016). In this way, it is possible to create a joint probability hazard map, which encompasses effects arising from any of the eruptions considered in this study, according to their relative 
weights. In contrast, the N100 case allows considering a longer time frame and the possibility on eruptive scenarios that are not mutually exclusive. These probabilities could be used for estimating the total cumulative hazard in the surrounding territory in the next decades.

The ESPs for which the uncertainty distributions have been quantified include most of those defined by Bonadonna et al. $(2012,2016)$ as those that need to be parametrized for the majority of existing plume and tephra transport/deposition numerical models. The list defined by Bonadonna et al. $(2012,2016)$ includes plume height, eruption mass, mass eruption rate (inferred from total mass and eruption duration), total grain-size distribution , and the onset and end of an eruption (defining eruption duration). With the exception of total grainsize distribution (not elicited for the reasons explained in section 3.1), we have therefore provided detailed uncertainty distributions for such ESPs. These distributions are not simply represented by uniform distributions between two extreme values, but they are characterized by a triplet of uncertainty values $\left(5^{\text {th }}, 50^{\text {th }}, 95^{\text {th }}\right.$ percentiles) and probability density functions obtained by kernel methods. This probabilistic approach is particularly beneficial if such parameterizations are used as inputs to numerical models for generating hazard maps, when iterative re-sampling of the elicited ESP distributions can capture epistemic or aleatoric uncertainties. When possible, the ESPs here defined have been compared with those available from literature. To this purpose, we compiled a list of well-studied eruptions (classified according to prevalent magma composition, VEI, eruptive style, total mass of fallout deposit and plume height) in Table C1 from Appendix C. While this list is limited and reflects the actual availability of detailed data, it however provides a first order comparison to evaluate the robustness of our estimations.

In the following two sub-sections, we discuss separately the implications for hazards at Cotopaxi and at Guagua Pichincha volcanoes. Concerning the ESPs for both volcanoes, as pointed out in section 4.1, average plume height has the lowest variability among the alternative scoring methods, likely due to the better availability of plume height measurements of eruptions with similar magnitudes/intensities, both at the studied volcanoes and worldwide (Mastin et al. 2009; Gouhier et al. 2019).

\subsubsection{Cotopaxi volcano}

The responses given by the experts were concordant in general and did not show evidence for "school of thoughts" when judging relative probabilities for rhyolitic and andesitic eruptions (i.e. the probability density functions of rhyolitic and andesitic magmas are unimodal for all three scoring methods). However, the high relative probability that an eruption at Cotopaxi will be andesitic is more pronounced for the NE case (Fig. 3a) than for the N100 case (Fig. 3b). The conditional probability of a rhyolitic eruption (as highlighted in section 4.1) is substantially lower than that of an andesitic eruption for both the NE and the N100 cases. This reflects the fact that the last rhyolitic eruption dates back to $2.1 \mathrm{ky} \mathrm{BP}$ (see section 2.1). Nevertheless it is very uncertain and not negligible, ranging from $0.4 \%$ to $50 \%$, with a median probability of $8-12 \%$ (mean values $13-20 \%$ ). We highlight that at Cotopaxi, eruptions involving rhyolitic magmas characterize mostly the early stages of the eruptive history of the volcano and, generally, deposits from old, low-magnitude eruptions are rarely preserved. From this point of view, the conditional probabilities assigned in Table 3, including the "Other type" case, reflect a conservative approach, in which the possibility of the incompleteness of the rhyolitic eruptive record (i.e. under-recording) is taken into consideration. The Plinian and sub-Plinian eruptions involving rhyolitic magmas have therefore a summed mean conditional probability (for the next eruption) of 11-14 \%, where the range of different values depends on the method selected. This mean probability is significantly higher for the N100 case (19-23\%). In this respect, the mean possibility of having at least one large-magnitude rhyolitic eruption is not negligible, and this has an effect on the expected volcanic hazard, as highlighted with their related ESPs (see below).

Considering andesitic eruptions, it is worth commenting on three aspects. First, similarly to rhyolitic eruptions, the possibility of an under-recording of old, low-magnitude andesitic eruptions could also not be excluded, considering that, according to Hall and Mothes (2008), andesitic magmas occurred within the F series (9.6-5.5 ka BP) rhyolitic eruptive episodes (see section 2.1). Second, the summed mean probability of subPlinian and Plinian eruptions involving andesitic magmas for the NE case is $19-27 \%$. Besides exhibiting a greater difference between the various scoring methods relative to rhyolitic cases, the conditional probability of a sub-Plinian or Plinian andesitic eruption is significantly higher than that for a rhyolitic eruption of similar size. This is an important point because, as mentioned earlier, the magma type can have an impact on the potential hazards (as implied by the different ranges of ESPs). Third, the "hydrovolcanic/continuous ash emission" eruption type is considered the most probable next eruption, under all scoring methods. This is consistent with Bernard et al. (2016), who underline that, despite the under-representation of VEI 1-2 eruptions in the geologic record, such an eruption type could be the most frequent ones at Cotopaxi (see also Wolf 1904). There is, however, large uncertainty associated with responses on eruption type probabilities, as highlighted by: i) the largest credible intervals between the $5^{\text {th }}$ and $95^{\text {th }}$ percentiles compared to other elicited items, for all three scoring methods and ii) the differences in multi-modal values depending on scoring method (Fig. 3). Moreover, 
differences between the alternative scoring methods are also greater, a fact that could be largely correlated to the less well-defined features of this eruption type compared to others (e.g. Plinian or sub-Plinian); the implications of this situation, discussed in section 5.1, should be therefore considered. It is important to highlight that, if we consider the sum of the mean probability of occurrences for any sub-Plinian and Plinian type eruption (rhyolitic or andesitic), we obtain a probability, for the next eruption NE, of 30-40\%. A comparison of our results with those of Biass and Bonadonna (2013) is not straightforward, due to some differences in the eruption classification scheme. While these authors focus on eruptions with a specific VEI for their analyses, we have used the terminology sub-Plinian and Plinian, which spans between VEIs. Moreover, Biass and Bonadonna (2013) specifically calculated the probabilities of VEI 3, 4, 5 for the next eruption of VEI $\geq 3$ in the next 100 years, without considering the occurrence of multiple events of different type in the next 100 years.

Nevertheless, we have calculated, from the values in Table 3, the NE and N100 $5^{\text {th }}, 50^{\text {th }}, 95^{\text {th }}$ probability percentiles, and the mean probability of Plinian eruptions involving either rhyolitic or andesitic magmas (CM method only). These values are, respectively, $[1.7,8.7,31]$ with mean value $12 \%$ for NE, and $[2.9,23,65]$ with mean value $27 \%$ for N100, and they are both consistent with the sum of the probabilities of VEI 4 and 5 eruptions (20.8\%) calculated by Biass and Bonadonna (2013) for the next 100 years at Cotopaxi. Specifically, it seems evident that our estimations, which include uncertainty ranges, fully capture the probability calculated by using other datasets.

From the point of view of the parameters that are considered (Table 5), rhyolitic Plinian and sub-Plinian eruptions are expected to have longer median durations than their andesitic counterparts; this is consistent between CM, ERF and EW methods. Their uncertainty ranges are, however, slightly more skewed toward $95^{\text {th }}$ percentile values than is the case in the andesitic scenarios. Andesitic eruptions with shorter durations are expected to have average plume height values that are slightly higher than those of rhyolitic eruptions, at least in terms of median values (for CM, ERF and EW). This implies, from a volcanic hazard point of view, a potentially longer duration of eruptive crises and potentially thicker deposits for rhyolitic eruptions than for andesitic ones. The judged longer duration of rhyolitic eruptions with respect to andesitic counterparts is partially confirmed by the eruptions considered in Table $\mathrm{C} 1$, since the mean of the durations for rhyolitic and andesitic eruptions are, respectively, 3300 and $790 \mathrm{~min}$ (both within our percentile ranges for both sub-Plinian and Plinian of Table 5). Concerning plume height, mean value from Table $\mathrm{C} 1$ are, for rhyolitic and andesitic eruptions, 18 and $19 \mathrm{~km}$ respectively. We recall, however, that plume height values from Table $\mathrm{C} 1$ are maximum plume heights, while our estimates are average plume heights.

The judged tephra fallout mass outputs for sub-Plinian and Plinian eruptions (both rhyolitic and andesitic) range from $10^{9}$ to $10^{12} \mathrm{~kg}$, with medians of $10^{10} \mathrm{~kg}$ for sub-Plinian and $10^{11} \mathrm{~kg}$ for Plinian, comparable to estimations made for similar eruptions at Cotopaxi (Biass and Bonadonna 2011). For hydrovolcanic/continuous ash emission eruptions, the judged tephra fallout mass is lower relative to other eruption types (median values are all around $10^{8} \mathrm{~kg}$ ), but their duration could be fairly long (median > 1 month see Table 5). Considering the highest conditional probability of these eruptions (both for the NE and the N100 ), long eruption durations have potentially severe consequences for aviation operations (Bernard et al. 2016) and for crop and greenhouses agriculture, the latter being one of Ecuador's most important sources of income (Knapp 2017).

\subsubsection{Guagua Pichincha volcano}

The case of Guagua Pichincha is less complex than that of Cotopaxi since the composition of erupted magmas and the eruption types are more homogeneous. Nevertheless, the issue of the completeness of the stratigraphic record still remains. Considering the three eruption types on the event tree in Figure $2 b$, only Vulcanian to dome-forming eruptions (1999-2001 cycle) and Plinian eruptions (AD 1660) have been observed directly. Despite their apparent absence in the geologic record, in our logic tree we have inserted also sub-Plinian eruptions because they are sometimes difficult to distinguish from Plinian eruptions or from large Vulcanian events. No other eruptions with lower VEIs (including phreatic ones) are present in the geological record, a fact that seems to be partially confirmed by the (scarce) historical accounts of the "Historic" cycle (see Table 2). However, similarly to Cotopaxi, the possibility of unrecorded eruptions is not negligible, essentially because Guagua Pichincha is close to a region (to the west) characterized by a wet climate that does not favor preservation of thin volcanic deposits.

Consistent with these observations, the probability of "Other type" eruptions has a non-negligible median value of $7.5-11 \%$ for the NE case (mean values of $13-18 \%$ ) and $7.9-13 \%$ for the N100 case (mean values of $13-22 \%$ ), considering all three scoring methods. The eruption type for which the conditional probability for all the scoring methods and both for the NE and N100 cases is highest is the Vulcanian type (median values are $40-55 \%$ and $56-66 \%$ for $\mathrm{NE}$ and N100 respectively; mean values of $40-51 \%$ and 52 $60 \%$ ), similar to the event that occurred during the 1999-2001 cycle. Again, in this case (as for the "hydrovolcanic/continuous ash emission" case of Cotopaxi, see previous section) greater uncertainties and 
differences in multimodal values (Fig. 4) arising from the scoring methods are limited and reasonably correlated with the less well-defined features of this eruption type compared to others (e.g. Plinian or sub-Plinian).

In this case study, the situation is similar to that of the hydrovolcanic/continuous ash emission eruption for Cotopaxi volcano (see section 5.2.1), where the probability density function of the CM scoring method differs from those of the ERF and EW methods (Table 4 and Fig. 4). We also remark that the summed mean conditional probabilities for Plinian and sub-Plinian eruptions are $26-43 \%$ (NE case) and $50-58 \%$ (N100 case). Pyroclastic density currents are likely to be one of the worst hazards of a Plinian or sub-Plinian eruption at Guagua Pichincha. However, due to topographic constraints, these currents are likely to be confined mainly to the poorly inhabited valleys to the NW and SW of the active crater (Robin et al. 2008). On the other hand, tephra fallout will represent a major hazard for the city of Quito, since there are historical accounts of ash fall during the AD 1660 eruption (Robin et al. 2008) but also during the much smaller AD 1999 Vulcanian eruption (Naumova et al. 2007; Volentik and Houghton 2015).

Finally, we underline that: i) ESPs from Table 6 are consistent both with other estimations for Guagua Pichincha volcanoes (e.g. total mass estimated by Barberi et al. 1992 for Layers 3/5) and values reported in Table C1; ii) there is a similarity between the elicited uncertainty distributions of ESPs for Plinian and subPlinian eruptions of Guagua Pichincha with those for the same-size eruption types with andesitic magmas at Cotopaxi volcano (Tables 5 and 6). This similarity represents consistent reasoning by our experts, since the magma compositions of Guagua Pichincha products are dacitic to andesitic (Robin et al. 2010).

\section{Conclusions}

This paper addresses the probabilities of different explosive eruption types and their main ESPs at Cotopaxi and Guagua Pichincha volcanoes. We analyzed these probabilities from both "next eruption" and "next 100 years" perspectives, through the employment of well-established structured expert judgment analysis procedures involving twenty experts with different backgrounds, professional interests and volcanological experiences. Results are presented, for each eruption parameter, as uncertainty distributions based on probability functions defined by three percentiles $\left(5^{\text {th }}, 50^{\text {th }}\right.$ and $\left.95^{\text {th }}\right)$. By employing different scoring methods with different features and advantages (the Classical Model, the Expected Relative Frequency method, and the Equal Weights pooling rule), the user of these elicitation data is given the opportunity to use the results from one single approach or to choose some combination of the results.

In addition, Principal Component Analysis was used for sensitivity testing the outcomes from different sub-groups of experts, the latter subdivided in terms of experience (A1/A2 - Experienced researchers/Earlycareer researchers), background (B1/B2 - Geologists/Mathematicians-Modelers) and institution affiliation at the time of the elicitation (C1/C2 - Clermont-Ferrand/Quito). Analysing results from the Classical Model highlights that the outcomes considering all the experts are equally distant from those of sub-groups $\mathrm{C} 1 / \mathrm{C} 2$, while they are closer to those of sub-groups A1 and B1 respectively. In other words, institutional affiliation was not a determinant of overall decision maker (DM) findings, whereas they were somewhat influenced by experienced researchers and by those with geological backgrounds.

Further studies should address two aspects: i) the incompleteness of the geologic record for both Cotopaxi and Guagua Pichincha volcanoes; ii) the causes of major sources of uncertainty highlighted by our expert judgment results. With respect to this latter point, an extended discussion of the rationale behind the ESPs estimates and probability forecasts could enhance their scientific impact. This includes the probability of occurrence and the ESPs of small size eruptions (hydrovolcanic/long-lasting ash emission for Cotopaxi, Vulcanian for Guagua Pichincha), the probability of occurrence and the ESPs of the rhyolitic eruptions of Cotopaxi, and the detailing of the 'other type' eruptions.

Nevertheless, the probability distributions were found to be robust with respect to different density estimation methods and expert aggregation models. Thus, the reported judgments picture the knowledge of the elicited group of experts, and they could only be modulated by any substantial new data set, information or interpretation of the volcanic record of Cotopaxi and Guagua Pichincha volcanoes. Notwithstanding the limitations of the analysis described above, our estimates represent crucial input information for the development of quantitative hazard and risk maps of eruptive phenomena in the region, especially for what concerns the uncertainty quantification. We remark, moreover, that our approach is not inconsistent with previous studies that involved an analysis of the past eruptive record (Biass and Bonadonna 2013). Nevertheless, we present some information that was rather difficult to obtain without using expert judgment techniques. In particular, we performed uncertainty quantification on the probability estimates provided and on the evaluation of the case of more than one type of eruption occurring in the next 100 years.

With respect to hazard implications for each volcano, the main results are: ash emission involving andesitic magma, similar to that of AD 2015. However, the chance of a 
rhyolitic event is not negligible although very uncertain, with a median probability of $8-12 \%$ (mean values 13-20\%). The median probability that there will be at least one eruption of this type within the next 100 years is $43-55 \%$ (mean values in $43-51 \%$ ). Despite these eruptions have relatively low magnitude/intensity, their long durations (median of $\sim 1$ month) can have a significant negative impact on aviation safety and both crop and greenhouse cultivations. For larger magnitude eruptions (i.e. sub-Plinian and Plinian), rhyolitic ones have lower probabilities of occurrences than andesitic ones, but they could pose a higher threat due to their potential longer durations and larger eruption masses than their andesitic counterparts. As a whole, summing the mean probabilities that the next eruption will be either sub-Plinian or Plinian (whether rhyolitic or andesitic) returns a substantial, significant mean probability of 30 - 40\%;

- for Guagua Pichincha, the most probable next eruption is a vulcanian event (similar to that of AD 1999), with a median probability of occurrence of $40-55 \%$ (mean values of $40-51 \%$ ). The median probability that within the next 100 years there will be at least one eruption of this type is greater: $55-66 \%$ (mean values of $52-60 \%$ ). The larger magnitude eruption types (sub-Plinian or Plinian) have, in turn, a summed mean probability of occurrence for the next eruption of $26-43 \%$, while for the next 100 years the same combined mean probability is of $50-58 \%$.

In summary, while small or moderate magnitude eruptions are considered most likely candidates for the next eruption at Cotopaxi and at Guagua Pichincha, the elicited event probabilities for violent explosive eruptions represent a plausible prospect at either volcano in the long or short term. Indeed, the possibility exists, at a non-trivial probability, that the next eruption in either case could be on the scale of a sub-Plinian or Plinian eruption.

\section{Appendix A: Performance-based Expert Judgment}

In general, with the performance-based elicitation procedure underpinning the Classical Model approach (Cooke 1991; Aspinall 2006), statistical accuracy (e.g. calibration) and informativeness scores are derived for each expert from a set of 'seed questions'. These items comprise factual questions, the true quantitative values of which an expert is not expected to know precisely but, in respect of which, he/she is expected to provide meaningful credible intervals that capture those values reliably and informatively, by informed reasoning.

Concerning the two scores, statistical accuracy (“calibration") represents the p-value that the expert's inter-quantile probabilities, summed over several items, match the underlying probability vector sample distribution implied by the $5^{\text {th }}, 50^{\text {th }}$ and $95^{\text {th }}$ percentiles, as assessed by the expert per item. If the actual realization values are indeed drawn independently from such a distribution, with quantiles as stated by the expert, then deviations in the expert's assessments are asymptotically distributed as a chi-square variable with 3 degrees of freedom. The corresponding p-value for goodness-of-fit yields a measure of the expert's statistical accuracy (or calibration). At the same time, the expert's informativeness score is the degree to which their uncertainty distributions are concentrated; that is, the smaller the distance between the $5^{\text {th }}$ and the $95^{\text {th }}$ percentiles, the more an expert is informative.

In general, it can be shown that these two performance-based scores in the Classical Model refer to "orthogonal" properties of the expert's judgment capability: i.e. their statistical accuracy versus informativeness. The challenge for the expert, therefore, is to optimize their overall performance score - which is the product of these two metrics - by maximizing them jointly. This is a tricky judgmental balancing act: the expert's performance score will be penalized if they over-accentuate one at the expense of the other by being more precise or more informative in their judgments on a question than their understanding of the uncertainty warrants.

With respect to the scoring methods mentioned in Section 3.1, the two performance-based methods CM (the Classical Model: Cooke 1991) and ERF (Expected Relative Frequency method; Flandoli et al. 2011) significantly differ in their scoring metrics: CM evaluates the statistical distribution of the known values with respect to the expert's percentiles, and, on a second order, the diameter of the corresponding uncertainty range; ERF measures the likelihood of "accurate" judgments, i.e. those relatively close to the true value of a question.

Variances of the performance scores, which indicate how they differ, tend to be highest with the CM approach, lower with ERF (and trivially null with the Equal Weights EW rule, which has no performance measure). We remark that for the purpose of defining the global decision makers (DMs) we always performed a weighted combination (probability mixture) of maximum entropy distributions. That is, we did not use triangular functions and quantile pooling when defining the DMs (Bevilacqua, 2016). This differs from the traditional approach followed in the ERF method but simplifies the comparison of the results by focusing only on the differences in the scores. We remark that the calculation of the ERF scores is still based on triangular functions. 
According to Flandoli et al. (2011), the main outcomes for each scoring methods are:

- The main advantage of using the CM method is that it is possible to highlight those experts with the best combination of calibration and informativeness scores (these are not measures of each expert's knowledge about the problem but indicate, objectively, their capability to express informative uncertainties about a range of subject matter items). In particular, when group's judgments are pooled, this latter aspect generally produces smaller (and thus more informative) uncertainty bounds between the $5^{\text {th }}$ and $95^{\text {th }}$ percentiles for each question. Moreover, Flandoli et al. (2011) demonstrate that the uncertainty range described by the CM is usually the best estimate of the supposed 'true' uncertainty;

- In contrast, the EW method describes the maximum uncertainty bounds (pointing toward a more "conservative" approach) but it does not take into account the information about individual expert's calibration (i.e. statistical accuracy) obtained from the seed questionnaire;

- Finally, the ERF method has been shown by Flandoli et al. (2011) to conceptually provide the most accurate estimates of supposed 'true' central values (i.e. the median values of the distributions).

For this study, during the first plenary session, the experts benefited from a detailed presentation of the eruptive history of the two volcanoes considered. Moreover, details about expert judgment techniques have been provided, which has been followed by final discussion on the topics presented. During the first part of the session, the experts were invited to provide their judgments on 16 seed questions. However, two questions had ambiguous formulations, which led to multiple interpretations by the experts. These questions were excluded from the performance scoring analysis for this reason. During the first stage, the experts were also asked to answer two different target questionnaires, respectively for Cotopaxi and Guagua Pichincha, whereby the experts were asked to evaluate the relative conditional probabilities of different eruptive styles/magma compositions over a single specific future timeframe (i.e. the next 100 years). After a first pass through the questions and following discussions with the experts, some issues were identified within the group's responses about several target items for both Cotopaxi and Guagua Pichincha. More specifically, some ambiguities were identified:

- for the meaning of the term "Magmatic Unrest"

- for the definition of an "Eruption"

- in the distinction between "Rhyolitic" and "Andesitic" magmas for Cotopaxi volcano

- in relation to questions about the future behavior of the volcano, queries were raised about whether the experts were considering "the next eruption" or an eruption in "the next 100 years", despite having separated the two frameworks of NE and N100.

In particular, it has been clarified to the participants that in this study the term "eruption" means a period of continuous volcanic activity, where the products erupted have almost the same composition and the geophysical signals are continuous, although fluctuant. In this sense, an eruption is separated from another eruption by a sufficiently long quiescence time (several months to years), where no volcanic activity is observed.

Because of these concerns (such issues usually arise with any expert elicitation), some question wordings were changed and other questions added to the set identifying which of the two alternative timeframes should be considered. The experts were then given the opportunity to revise their responses via email after some clarification notes and additional information were circulated to the participants. It is important to underline that experts have not been asked to provide an explanation to their answers.

\section{Appendix B: calculated mean values from probability distributions}

In this appendix we report the calculated means for the probability distributions from Tables 3-6. Such values have been calculated for both Cotopaxi (Table B1) and Guagua Pichincha (Table B2). It is worth mentioning that the sum of the mean probabilities of mutually exclusive scenarios sum to $100 \%$ in the NE case. In contrast, the sum is greater than $100 \%$ in the N100 case, because the possible occurrence of more than one type of eruption in the next 100 years was not excluded.

\section{Appendix C: comparison of some ESPs with global data}

Table $\mathrm{C} 1$ gives the data of the duration of well-studied eruptions involving, respectively, andesitic, dacitic, and rhyolitic magmas. To improve consistency of our approach with the reported data, the definition of eruption used for calculating durations is different with respect to the one reported in Appendix A, and it reflects the definition of eruption duration proposed by Mastin et al. (2009), which is to be the time period over which a significant amount of ash is continuously emitted into the atmosphere. Plume heights are maximum estimations. 
References.

Andújar J, Martel C, Pichavant M, Samaniego P, Scaillet B, Molina I (2017) Structure of the plumbing system at Tungurahua volcano, Ecuador: insights from phase equilibrium experiments on July-August 2006 eruption products. Journal of Petrology 58:1249-1278 doi:https://doi.org/10.1093/petrology/egx054

Aspinall WP (2006) Structured elicitation of expert judgment for probabilistic hazard and risk assessment in volcanic eruptions. Statistics in volcanology 1:15-30

Aspinall WP, Carniel R, Jaquet O, Woo G, Hincks T (2006) Using hidden multi-state Markov models with multi-parameter volcanic data to provide empirical evidence for alert level decision-support. Journal of Volcanology and Geothermal Research doi:https://doi.org/10.1016/j.jvolgeores.2005.08.010

Aspinall WP, Cooke RM (2013) Quantifying scientific uncertainty from expert judgment elicitation. In: Rougier J, Sparks RSJ, Hill LJ (eds) Risk and uncertainty assessment for natural hazards. Cambridge University Press, New York, pp 64-99. doi:www.cambridge.org/9781107006195

Aspinall WP, Woo G (2014) Santorini unrest 2011-2012: an immediate Bayesian belief network analysis of eruption scenario probabilities for urgent decision support under uncertainty. Journal of Applied Volcanology 3:1-12 doi:https://doi.org/10.1186/s13617-014-0012-8

Aspinall WP, Bevilacqua A, Costa A, Inakura H, Mahony S, Neri A, Sparks RSJ (2019) Probabilistic reconstruction (or forecasting) of distal runouts of large magnitude ignimbrite PDC flows sensitive to topography using mass-dependent inversion models. In: AGU Fall Meeting 2019, San Francisco, CA, USA, 2019. doi:doi.org/10.1002/essoar.10502300.1

Barberi F, Ghigliotti M, Macedonio G, Orellana H, Pareschi MT, Rosi M (1992) Volcanic hazard assessment of Guagua Pichincha (Ecuador) based on past behaviour and numerical models. Journal of Volcanology and Geothermal Research 49:53-68 doi:https://doi.org/10.1016/0377-0273(92)90004-W

Barberi F, Coltelli M, Frullani A, Rosi M, Almeida E (1995) Chronology and dispersal characteristics of recently (last 5000 years) erupted tephra of Cotopaxi (Ecuador): implications for long-term eruptive forecasting. Journal of Volcanology and Geothermal research 69:217-239 doi:https://doi.org/10.1016/03770273(95)00017-8

Bebbington MS, Cronin SJ (2011) Spatio-temporal hazard estimation in the Auckland Volcanic Field, New Zealand, with a new event-order model. Bulletin of Volcanology 73:55-72 doi:https://doi.org/10.1007/s00445-010-0403-6

Bebbington MS, Stirling MW, Cronin SJ, Wang T, Jolly G (2018) National-level long-term eruption forecasts by expert elicitation. Bulletin of Volcanology 80:56 doi:https://doi.org/10.1007/s00445-018-1230-4

Bernard B, Battaglia J, Proaño A, Hidalgo S, Vásconez F, Hernandez S, Ruiz MC (2016) Relationship between volcanic ash fallouts and seismic tremor: quantitative assessment of the 2015 eruptive period at Cotopaxi volcano, Ecuador. Bulletin of Volcanology 78 doi:10.1007/s00445-016-1077-5

Bevilacqua A, Isaia R, Neri A, Vitale S, Aspinall WP, Bisson M, Flandoli F, Baxter PJ, Bertagnini A, Esposti Ongaro T, Iannuzzi E, Pistolesi M, Rosi M (2015) Quantifying volcanic hazard at Campi Flegrei caldera (Italy) with uncertainty assessment: I. Vent opening maps. Journal of Geophysical Research: Solid Earth 120:2309-2329 doi:https://doi.org/10.1002/2014JB011775

Bevilacqua A (2016) Doubly stochastic models for volcanic hazard assessment at Campi Flegrei caldera. PhD Theses. Birkhäuser/Springer, Pisa. doi:https://doi.org/10.1007/978-88-7642-577-6

Bevilacqua A, Flandoli F, Neri A, Isaia R, Vitale S (2016) Temporal models for the episodic volcanism of Campi Flegrei caldera (Italy) with uncertainty quantification. Journal of Geophysical Research: Solid Earth 121:7821-7845 doi:https://doi.org/10.1002/2016JB013171

Bevilacqua A, Bursik MI, Patra AK, Pitman BE, Yang Q, Sangani R, Kobs- Nawotniak S (2018) Late Quaternary eruption record and probability of future volcanic eruptions in the Long Valley volcanic region (CA, USA). Journal of Geophysical Research: Solid Earth 123:5466-5494 doi:https://doi.org/10.1029/2018JB015644

Bevilacqua A, Pitman EB, Patra AK, Neri A, Bursik MI, Voight B (2019) Probabilistic enhancement of the Failure Forecast Method using a stochastic differential equation and application to volcanic eruption forecasts. Frontiers in Earth Science 7 doi:https://doi.org/10.3389/feart.2019.00135

Bevilacqua A, Bertagnini A, Pompilio M, Landi P, Del Carlo P, Di Roberto A, Aspinall WP, Neri A (2020a) Major explosions and paroxysms at Stromboli (Italy): a new historical catalog and temporal models of occurrence with uncertainty quantification. Scientific Reports 10 doi:https://doi.org/10.1038/s41598020-74301-8

Bevilacqua A, Patra AK, Pitman EB, Bursik MI, De Martino P, Giudicepietro F, Macedonio G, Vitale S, Flandoli F, Voight B (2020b) Utilizzo preliminare del failure forecast method sui dati GPS di spostamento orizzontale registrati nella caldera dei Campi Flegrei dal 2011 al 2020. Miscellanea INGV 57:135-139 doi:https://doi.org/10.13127/misc/57/25 English version: arXiv:2007.02756 
Bevilacqua A, Patra AK, Pitman EB, Bursik MI, De Martino P, Giudicepietro F, Ricciolino P, Macedonio G, Vitale S, Flandoli F, Voight B (2020c) The Failure Forecast Method applied to the GPS and seismic data collected in the Campi Flegrei caldera (Italy) in 2011-2020. In: AGU Fall Meeting, San Francisco, 1-17/12/2020 2020c. doi:https://doi.org/10.1002/essoar.10505832.1

Biass S, Bonadonna C (2011) A quantitative uncertainty assessment of eruptive parameters derived from tephra deposits: the example of two large eruptions of Cotopaxi volcano, Ecuador. Bulletin of Volcanology 73:73-90

Biass S, Bonadonna C (2013) A fast GIS-based risk assessment for tephra fallout: the example of Cotopaxi volcano, Ecuador. Natural Hazards 65:477-495 doi:https://doi.org/10.1007/s11069-012-0378-z

Biass S, Frischknecht C, Bonadonna C (2013) A fast GIS-based risk assessment for tephra fallout: the example of Cotopaxi volcano, Ecuador - Part II: vulnerability and risk assessment. Natural hazards 65:497-521 doi:https://doi.org/10.1007/s11069-012-0457-1

Biass S, Scaini C, Bonadonna C, Folch A, Smith K, Höskuldsson A (2014) A multi-scale risk assessment for tephra fallout and airborne concentration from multiple Icelandic volcanoes-Part 1: Hazard assessment. Natural Hazards and Earth System Sciences 14:2265 doi:10.5194/nhess-14-2265-2014

Biass S, Todde A, Cioni R, Pistolesi M, Geshi N, Bonadonna C (2017) Potential impacts of tephra fallout from a large-scale explosive eruption at Sakurajima volcano, Japan. Bulletin of Volcanology 79:73 doi:https://doi.org/10.1007/s00445-017-1153-5

Bonadonna C, Phillips JC (2003) Sedimentation from strong volcanic plumes. Journal of Geophysical Research: Solid Earth 108 doi:https://doi.org/10.1029/2002JB002034

Bonadonna C, Connor CB, Houghton BF, Connor LJ, Byrne M, Laing A, Hincks TK (2005) Probabilistic modeling of tephra dispersal: Hazard assessment of a multiphase rhyolitic eruption at Tarawera, New Zealand. Journal of Geophysical Research: Solid Earth 110 doi:https://doi.org/10.1029/2003JB00289

Bonadonna C, Folch A, Loughlin S, Puempel H (2012) Future developments in modelling and monitoring of volcanic ash clouds: outcomes from the first IAVCEI-WMO workshop on Ash Dispersal Forecast and Civil Aviation. Bulletin of volcanology 74:1-10 doi:https://doi.org/10.1007/s00445-011-0508-6

Bonadonna C, Cioni R, Pistolesi M, Elissondo M, Baumann V (2015) Sedimentation of long-lasting windaffected volcanic plumes: the example of the 2011 rhyolitic Cordón Caulle eruption, Chile. Bulletin of Volcanology $77: 13$

Bonadonna C, Cioni R, Costa A, Druitt TH, Phillips JC, Pioli L, Andronico D, Harris AJL, Scollo S, Bachmann O, Bagheri G, Biass S, Brogi F, Cashman KV, Dominguez L, Dürig T, Galland O, Giordano G, Gudmundsson M, Hort M, Höskuldsson Á, Houghton BF, Komorowski JC, Küppers U, Lacanna G, Le Pennec JL, Macedonio G, Manga M, Manzella I, de'Michieli Vitturi M, Neri A, Pistolesi M, Polacci M, Ripepe M, Rossi E, Scheu B, Sulpizio R, Tripoli B, Valade S, Valentine GA, Vidal C, Wallenstein N (2016) MeMoVolc report on classification and dynamics of volcanic explosive eruptions. Bulletin of volcanology 78:84 doi:https://doi.org/10.1007/s00445-016-1071-y

Bonasia R, Capra L, Costa A, Macedonio G, Saucedo R (2011) Tephra fallout hazard assessment for a Plinian eruption scenario at Volcán de Colima (Mexico). Journal of Volcanology and Geothermal Research 203:12-22 doi:https://doi.org/10.1016/j.jvolgeores.2011.03.006

Carey RJ, Houghton BF, Thordarson T (2010) Tephra dispersal and eruption dynamics of wet and dry phases of the 1875 eruption of Askja Volcano, Iceland. Bulletin of Volcanology 72:259-278 doi:https://doi.org/10.1007/s00445-009-0317-3

Chiasera B, Cortés JA (2011) Predictive regions for geochemical compositional data of volcanic systems. Journal of Volcanology and Geothermal Research 207:83-92 doi:https://doi.org/10.1016/j.jvolgeores.2011.07.009

Christophersen A, Deligne NI, Hanea AM, Chardot L, Fournier N, Aspinall WP (2018) Bayesian Network modeling and expert elicitation for probabilistic eruption forecasting: pilot study for Whakaari/White Island, New Zealand. Frontiers in Earth Science 6:211 doi:https://doi.org/10.3389/feart.2018.00211

Coles SG, Sparks RSJ (2006) Extreme value methods for modelling historical series of large volcanic magnitudes. In: Mader HM, Coles SG, Connor CB, Connor LJ (eds) Statistics in volcanology, vol 1. IAVCEI Speial Publication. Geological Society, London, pp 47-56

Connor CB, Connor LJ (2009) Estimating spatial density with kernel methods. Volcanic and tectonic hazard assessment for nuclear facilities Cambridge University Press, Cambridge, UK:346-368

Connor CB, Bebbington MS, Marzocchi W (2015) Probabilistic volcanic hazard assessment. In: Sigurdsson H, Houghton BF, McNutt SR, Rymer H, Stix J (eds) The Encyclopedia of Volcanoes. Elsevier, pp 897910. doi:https://doi.org/10.1016/B978-0-12-385938-9.00051-1

Cooke RM (1991) Experts in uncertainty: opinion and subjective probability in science.

Costa A, Dell'Erba F, Di Vito MA, Isaia R, Macedonio G, Orsi G, Pfeiffer T (2009) Tephra fallout hazard assessment at the Campi Flegrei caldera (Italy). Bulletin of Volcanology 71:259 doi:https://doi.org/10.1007/s00445-008-0220-3 
Costa A, Pioli L, Bonadonna C (2016) Assessing tephra total grain-size distribution: Insights from field data analysis. Earth and Planetary Science Letters 443:90-107 doi:https://doi.org/10.1016/j.epsl.2016.02.040

De la Cruz-Reyna S (1993) Random patterns of occurrence of explosive eruptions at Colima Volcano, Mexico. Journal of Volcanology and Geothermal research 55:51-68 doi:https://doi.org/10.1016/03770273(93)90089-A

Deligne NI, Coles SG, Sparks RSJ (2010) Recurrence rates of large explosive volcanic eruptions. Journal of Geophysical Research: Solid Earth 115 doi:https://doi.org/10.1029/2009JB006554

Deligne NI, Sparks RSJ, Brown SK (2017) Report on potential sampling biases in the LaMEVE database of global volcanism. Journal of Applied Volcanology 6:1-5 doi:https://doi.org/10.1186/s13617-017-00585

Durant AJ, Villarosa G, Rose WI, Delmelle P, Prata AJ, Viramonte JG (2012) Long-range volcanic ash transport and fallout during the 2008 eruption of Chaitén volcano, Chile. Physics and Chemistry of the Earth, Parts A/B/C 45:50-64 doi:https://doi.org/10.1016/j.pce.2011.09.004

Flandoli F, Giorgi E, Aspinall WP, Neri A (2011) Comparison of a new expert elicitation model with the Classical Model, equal weights and single experts, using a cross-validation technique. Reliability Engineering \& System Safety 96:1292-1310 doi:https://doi.org/10.1016/j.ress.2011.05.012

Furlan C (2010) Extreme value methods for modelling historical series of large volcanic magnitudes. Statistical Modelling 10:113-132 doi:https://doi.org/10.1177/1471082X0801000201

Garcia-Aristizabal A, Kumagai H, Samaniego P, Mothes P, Yepes H, Monzier M (2007) Seismic, petrologic, and geodetic analyses of the 1999 dome-forming eruption of Guagua Pichincha volcano, Ecuador. Journal of volcanology and geothermal research 161:333-351 doi:https://doi.org/10.1016/j.jvolgeores.2006.12.007

Gaunt HE, Bernard B, Hidalgo S, Proaño A, Wright HM, Mothes P, Criollo E, Kueppers U (2016) Juvenile magma recognition and eruptive dynamics inferred from the analysis of ash time series: The 2015 reawakening of Cotopaxi volcano. Journal of Volcanology and Geothermal Research 328:134-146 doi:https://doi.org/10.1016/j.jvolgeores.2016.10.013

Geotermica Italiana (1989) Mitigaciòn del Riesgo Volcanico en el Area Metropolitana de Quito. Ministero Affari Esteri Italiano, Pisa

Global Volcanism Program (2013) Volcanoes of the world, v. 4.8.7, E. Venzke, Smithsonian Institution. Accessed 18/03/2020

Gouhier M, Eychenne J, Azzaoui N, Guillin A, Deslandes M, Poret M, Costa A, Husson P (2019) Low efficiency of large volcanic eruptions in transporting very fine ash into the atmosphere. Scientific reports 9:1-12 doi:https://doi.org/10.1038/s41598-019-38595-7

Hall ML, Mothes PA (2008) The rhyolitic-andesitic eruptive history of Cotopaxi volcano, Ecuador. Bull Volc 70:675-702 doi:https://doi.org/10.1007/s00445-007-0161-2

Hidalgo S, Battaglia J, Arellano S, Sierra D, Bernard B, Parra R, Kelly P, Dinger F, Barrington C, Samaniego P (2018) Evolution of the 2015 Cotopaxi eruption revealed by combined geochemical and seismic observations. Geochemistry, Geophysics, Geosystems 19:2087-2108 doi:https://doi.org/10.1029/2018GC007514

Hincks TK, Komorowski JC, Sparks RSJ, Aspinall WP (2014) Retrospective analysis of uncertain eruption precursors at La Soufrière volcano, Guadeloupe, 1975-77: volcanic hazard assessment using a Bayesian Belief Network approach. Journal of Applied Volcanology 3:3 doi:https://doi.org/10.1186/2191-50403-3

Kilburn CRJ (2018) Forecasting volcanic eruptions: beyond the Failure Forecast Method. Frontiers in Earth Science 6:133 doi:https://doi.org/10.3389/feart.2018.00133

Kiyosugi K, Connor CB, Sparks RSJ, Crosweller HS, Brown SK, Siebert L, Wang T, Takarada S (2015) How many explosive eruptions are missing from the geologic record? Analysis of the quaternary record of large magnitude explosive eruptions in Japan. Journal of Applied Volcanology 4:1-15 doi:https://doi.org/10.1186/s13617-015-0035-9

Knapp G (2017) Mountain agriculture for global markets: The case of greenhouse floriculture in Ecuador. Annals of the American Association of Geographers 107:511-519 doi:https://doi.org/10.1080/24694452.2016.1203282

Macedonio G, Costa A, Scollo S, Neri A (2016) Effects of eruption source parameter variation and meteorological dataset on tephra fallout hazard assessment: example from Vesuvius (Italy). Journal of Applied Volcanology 5:1

Martel C, Andújar J, Mothes P, Scaillet B, Pichavant M, Molina I (2018) Storage conditions of the mafic and silicic magmas at Cotopaxi, Ecuador. Journal of Volcanology and Geothermal Research 354:74-86

Martí J, Aspinall WP, Sobradelo R, Felpeto A, Geyer A, Ortiz R, Baxter PJ, Cole PD, Pacheco J, Blanco MJ (2008) A long-term volcanic hazard event tree for Teide-Pico Viejo stratovolcanoes (Tenerife, Canary 
Islands). Journal of Volcanology and Geothermal Research doi:https://doi.org/10.1016/j.jvolgeores.2008.09.023

Marzocchi W, Bebbington MS (2012) Probabilistic eruption forecasting at short and long time scales. Bulletin of volcanology 74:1777-1805 doi:https://doi.org/10.1007/s00445-012-0633-x

Mastin LG, Guffanti M, Servranckx R, Webley P, Barsotti S, Dean K, Durant AJ, Ewert JW, Neri A, Rose WI, Schneider D, Siebert L, Stunder BJB, Swanson G, Tupper A, Volentik ACM, Waythomas CF (2009) A multidisciplinary effort to assign realistic source parameters to models of volcanic ash-cloud transport and dispersion during eruptions. Journal of Volcanology and Geothermal Research 186:10-21 doi:https://doi.org/10.1016/j.jvolgeores.2009.01.008

Mothes PA, Hall ML, Janda RJ (1998) The enormous Chillos Valley Lahar: an ash-flow-generated debris flow from Cotopaxi Volcano, Ecuador. Bulletin of Volcanology 59:233-244 doi:https://doi.org/10.1007/s004450050188

Mulargia F, Tinti S, Boschi E (1985) A statistical analysis of flank eruptions on Etna volcano. Journal of volcanology and geothermal research 23:263-272 doi:https://doi.org/10.1016/0377-0273(85)90037-X

Naumova EN, Yepes H, Griffiths JK, Sempértegui F, Khurana G, Jagai JS, Játiva E, Estrella B (2007) Emergency room visits for respiratory conditions in children increased after Guagua Pichincha volcanic eruptions in April 2000 in Quito, Ecuador observational study: time series analysis. Environmental Health 6:21 doi:https://doi.org/10.1186/1476-069X-6-21

Neri A, Aspinall WP, Cioni R, Bertagnini A, Baxter PJ, Zuccaro G, Andronico D, Barsotti S, Cole PD, Esposti Ongaro T (2008) Developing an event tree for probabilistic hazard and risk assessment at Vesuvius. Journal of Volcanology and Geothermal Research 178:397-415 doi:https://doi.org/10.1016/j.jvolgeores.2008.05.014

Newhall CG, Hoblitt RP (2002) Constructing event trees for volcanic crises. Bulletin of Volcanology 64:3-20 doi:https://doi.org/10.1007/s004450100173

Papale P (2018) Global time-size distribution of volcanic eruptions on Earth. Scientific reports 8:1-11 doi:https://doi.org/10.1038/s41598-018-25286-y

Parra R, Bernard B, Narváez D, Le Pennec JL, Hasselle N, Folch A (2016) Eruption Source Parameters for forecasting ash dispersion and deposition from vulcanian eruptions at Tungurahua volcano: Insights from field data from the July 2013 eruption. Journal of Volcanology and Geothermal Research 309:1-13 doi:https://doi.org/10.1016/j.jvolgeores.2015.11.001

Pistolesi M, Rosi M, Cioni R, Cashman KV, Rossotti A, Aguilera E (2011) Physical volcanology of the posttwelfth-century activity at Cotopaxi volcano, Ecuador: Behavior of an andesitic central volcano. Geological Society of America Bulletin 123:1193-1215 doi:https://doi.org/10.1130/B30301.1

Poland MP, Anderson KR (2020) Partly Cloudy With a Chance of Lava Flows: Forecasting Volcanic Eruptions in the Twenty- First Century. Journal of Geophysical Research: Solid Earth 125 doi:https://doi.org/10.1029/2018JB016974

Riley CM, Rose WI, Bluth GJS (2003) Quantitative shape measurements of distal volcanic ash. Journal of Geophysical Research: Solid Earth 108 doi:https://doi.org/10.1029/2001JB000818

Risacher F, Alonso H (2001) Geochemistry of ash leachates from the 1993 Lascar eruption, northern Chile. Implication for recycling of ancient evaporites. Journal of volcanology and geothermal research 109:319-337 doi:https://doi.org/10.1016/S0377-0273(01)00198-6

Robertson RM, Kilburn CRJ (2016) Deformation regime and long-term precursors to eruption at large calderas: Rabaul, Papua New Guinea. Earth and Planetary Science Letters 438:86-94 doi:https://doi.org/10.1016/j.eps1.2016.01.003

Robin C, Samaniego P, Le Pennec JL, Mothes PM, Van Der Plicht J (2008) Late Holocene phases of dome growth and Plinian activity at Guagua Pichincha volcano (Ecuador). J Volcanol Geoth Res 176:7-15 doi:https://doi.org/10.1016/j.jvolgeores.2007.10.008

Robin C, Samaniego P, Le Pennec JL, Fornari M, Mothes PA, Van Der Plicht J (2010) New radiometric and petrological constraints on the evolution of the Pichincha volcanic complex (Ecuador). Bulletin of volcanology 72:1109-1129 doi:https://doi.org/10.1007/s00445-010-0389-0

Rougier J, Sparks RSJ, Cashman KV (2016) Global recording rates for large eruptions. Journal of Applied Volcanology 5:1-10 doi:https://doi.org/10.1186/s13617-016-0051-4

Rougier J, Sparks RSJ, Cashman KV (2018) Regional and global under-recording of large explosive eruptions in the last 1000 years. Journal of Applied Volcanology 7:1-10 doi:https://doi.org/10.1186/s13617-0170070-9

Runge MG, Bebbington MS, Cronin SJ, Lindsay JM, Kenedi CL, Moufti MRH (2014) Vents to events: determining an eruption event record from volcanic vent structures for the Harrat Rahat, Saudi Arabia. Bulletin of Volcanology 76:804 doi:https://doi.org/10.1007/s00445-014-0804-z

Samaniego P, Robin C, Chazot G, Bourdon E, Cotten J (2010) Evolving metasomatic agent in the Northern Andean subduction zone, deduced from magma composition of the long-lived Pichincha volcanic 

doi:https://doi.org/10.1007/s00410-009-0475-5

Sandri L, Costa A, Selva J, Tonini R, Macedonio G, Folch A, Sulpizio R (2016) Beyond eruptive scenarios: assessing tephra fallout hazard from Neapolitan volcanoes. Scientific reports 6:1-13 doi:https://doi.org/10.1038/srep24271

Sheldrake TE (2014) Long-term forecasting of eruption hazards: A hierarchical approach to merge analogous eruptive histories. Journal of volcanology and geothermal research 286:15-23 doi:https://doi.org/10.1016/j.jvolgeores.2014.08.021

Sheldrake TE, Sparks RSJ, Cashman KV, Wadge G, Aspinall WP (2016) Similarities and differences in the historical records of lava dome-building volcanoes: Implications for understanding magmatic processes and eruption forecasting. Earth-Science Reviews 160:240-263 doi:https://doi.org/10.1016/j.earscirev.2016.07.013

Silverman BW (1986) Density estimation for statistics and data analysis. vol 26. CRC press,

Smyth MA, Clapperton C (1986) Late Quaternary volcanic debris avalanche at Cotopaxi, Ecuador. Revista Centro Interandino Americano de Fotointerpretación CIAF (Bogotá) 11:24-38

Tadini A, Bevilacqua A, Neri A, Cioni R, Aspinall WP, Bisson M, Isaia R, Mazzarini F, Valentine GAV, Vitale S, Baxter PJ, Bertagnini A, Cerminara M, de' Michieli Vitturi M, Di Roberto A, Engwell SL, Esposti Ongaro T, Flandoli F, Pistolesi M (2017a) Assessing future vent opening locations at the SommaVesuvio volcanic complex: 2. Probability maps of the caldera for a future Plinian/sub-Plinian event with uncertainty quantification. Journal of Geophysical Research: Solid Earth 122:4357-4376 doi:10.1002/2016JB013860

Tadini A, Bisson M, Neri A, Cioni R, Bevilacqua A, Aspinall WP (2017b) Assessing future vent opening locations at the Somma-Vesuvio volcanic complex: 1. A new information geo-database with uncertainty characterizations. Journal of Geophysical Research: Solid Earth 122:4336-4356 doi:10.1002/2016JB013858

Tadini A, Roche O, Samaniego P, Guillin A, Azzaoui N, Gouhier M, de' Michieli Vitturi M, Pardini F, Eychenne J, Bernard B (2020) Quantifying the uncertainty of a coupled plume and tephra dispersal model: PLUME- MOM/HYSPLIT simulations applied to Andean volcanoes. Journal of Geophysical Research: Solid Earth 125 doi:https://doi.org/10.1029/2019JB018390

Tierz P, Clarke B, Calder ES, Dessalegn F, Lewi E, Yirgu G, Fontijn K, Crummy JM, Bekele Y, Loughlin SC (2020) Event trees and epistemic uncertainty in long- term volcanic hazard assessment of rift volcanoes: the example of Aluto (Central Ethiopia). Geochemistry, Geophysics, Geosystems doi:https://doi.org/10.1029/2020GC009219

Tsunematsu K, Bonadonna C (2015) Grain-size features of two large eruptions from Cotopaxi volcano (Ecuador) and implications for the calculation of the total grain-size distribution. Bulletin of Volcanology 77:64 doi:https://doi.org/10.1007/s00445-015-0949-4

Vázquez R, Bonasia R, Folch A, Arce JL, Macías JL (2019) Tephra fallout hazard assessment at Tacaná volcano (Mexico). Journal of South American Earth Sciences 91:253-259 doi:https://doi.org/10.1016/j.jsames.2019.02.013

Vezzoli L, Apuani T, Corazzato C, Uttini A (2017) Geological and geotechnical characterization of the debris avalanche and pyroclastic deposits of Cotopaxi Volcano (Ecuador). A contribute to instability-related hazard studies. Journal of Volcanology and Geothermal Research 332:51-70 doi:https://doi.org/10.1016/j.jvolgeores.2017.01.004

Voight B (1988) A method for prediction of volcanic eruptions. Nature 332:125-130 doi:https://doi.org/10.1038/332125a0

Volentik ACM, Houghton BF (2015) Tephra fallout hazards at Quito International Airport (Ecuador). Bulletin of Volcanology 77:50 doi:https://doi.org/10.1007/s00445-015-0923-1

Wang T, Bebbington MS (2012) Estimating the likelihood of an eruption from a volcano with missing onsets in its record. Journal of volcanology and geothermal research 243:14-23 doi:https://doi.org/10.1016/j.jvolgeores.2012.06.032

Wold S, Esbensen K, Geladi P (1987) Principal component analysis. Chemometrics and intelligent laboratory systems 2:37-52 doi:https://doi.org/10.1016/0169-7439(87)80084-9

Wolf T (1904) Crónica de los fenómenos volcánicos y terremotos en el Ecuador con algunas noticias sobre otros países de la América Central y Meridional desde 1535 hasta 1797. Imprenta de la Universidad Central de Quito, Quito. doi:http://www.dspace.uce.edu.ec/handle/25000/14200

Wright HMN, Cashman KV, Rosi M, Cioni R (2007) Breadcrust bombs as indicators of Vulcanian eruption dynamics at Guagua Pichincha volcano, Ecuador. Bulletin of Volcanology 69:281-300 doi:https://doi.org/10.1007/s00445-006-0073-6 


\section{FIGURE CAPTIONS}

Figure 1. a) Location of Cotopaxi and Guagua Pichincha volcanoes. b) and c) are enlargements of a). Coordinates expressed in the UTM WGS84 17S coordinate system. Service Layer Credits, source: Esri, DigitalGlobe, GeoEye, Earthstar Geographics, CNES/Airbus DS, USDA, USGS, AeroGRID, IGN and the GIS User Community.

Figure 2. Logic trees for a) Cotopaxi and b) Guagua Pichincha volcanoes. Each of the lowest branch of the logic trees represents a possible eruptive scenario with the maximum expected eruptive style.

Figure 3. Cotopaxi volcano. Probability density functions of conditional probabilities for a) the next eruption and $b$ ) the next 100 years. For each graph, it is reported on the x-axis the Decision Maker's response (in \%), and on the y-axis the distributions of, respectively, the Classical Model (red), the Expected Relative Frequency (blue) and the Equal Weight (green) Decision Makers.

Figure 4. Guagua Pichincha volcano. Probability density functions of conditional probabilities for a) the next eruption and b) the next 100 years. For each graph, it is reported on the X-axis the Decision Maker's response (in $\%$ ), and the distributions of, respectively, the Classical Model (red), the Expected Relative Frequency (blue) and the Equal Weight (green) Decision Makers.

Figure 5. Eigenvectors of the different sub-groups (A1 - Senior researchers; A2 - Early-career researchers; B1 Geologists; B2 - Mathematicians/Modelers; C1 - Clermont-Ferrand; C2 - Quito) plotted against the eigenvector of the whole group of experts (All). All the eigenvectors have been derived from the solutions of the Classical Model (CM) listed in Tables 3-6. Dim1 and Dim2 are the percentages of the $\mathrm{x}$ and $\mathrm{y}$ component of each eigenvector.

\section{TABLE CAPTIONS}

Table 1. Selected eruptions from Cotopaxi volcano used to define the typologies of eruption that compose logic trees of Figure 2. References: ${ }^{1}$ Hall and Mothes (2008); ${ }^{2}$ Pistolesi et al. (2011); ${ }^{3}$ Tsunematsu and Bonadonna (2015); ${ }^{4}$ Bernard et al. (2016).

Table 2. Selected eruptions from Guagua Pichincha volcano used to define the typologies of eruption that compose logic trees of Figure 2. References: ${ }^{1}$ Barberi et al. (1992); ${ }^{2}$ Robin et al. (2008); ${ }^{3}$ Robin et al. (2010).

Table 3. Conditional probabilities of different eruption types for the "next eruption" (NE) and "next 100 years" (N100) cases at Cotopaxi.

Table 4. Conditional probabilities of different eruption types for the "next eruption" (NE) and "next 100 years" (N100) cases at Guagua Pichincha.

Table 5. Uncertainty ranges for eruptive source parameters of Cotopaxi volcano. For durations, 1 day $=1440$ min., 1 week = 10080 min., 1 month = 43200 min., 1 year $=525600 \mathrm{~min}$.

Table 6. Uncertainty ranges for eruptive source parameters of Guagua Pichincha volcano. For durations, 1 day = 1440 min., 1 week = 10080 min., 1 month = $43200 \mathrm{~min} ., 1$ year $=525600 \mathrm{~min}$.

Table B1. Mean values for the probability of occurrences (next eruption NE and next 100 years N100) for the classical model (CM), expected relative frequency (ERF) and equal weight (EW) rule for Cotopaxi and Guagua Pichincha volcanoes.

Table B2. Mean values for the eruptive source parameters (duration, total mass of the tephra fallout deposit and average plume height) for the classical model (CM), expected relative frequency (ERF) and equal weight (EW) rule for Cotopaxi and Guagua Pichincha volcanoes.

Table C1. Selected eruptions involving andesitic, dacitic and rhyolitic magmas. References: ${ }^{1}$ Gouhier et al. (2019); ${ }^{2}$ Mastin et al. (2009); ${ }^{3}$ Risacher and Alonso (2001); ${ }^{4}$ Carey et al. (2010); ${ }^{5}$ Bonadonna et al. (2015); ${ }^{6}$ Durant et al. (2012). 


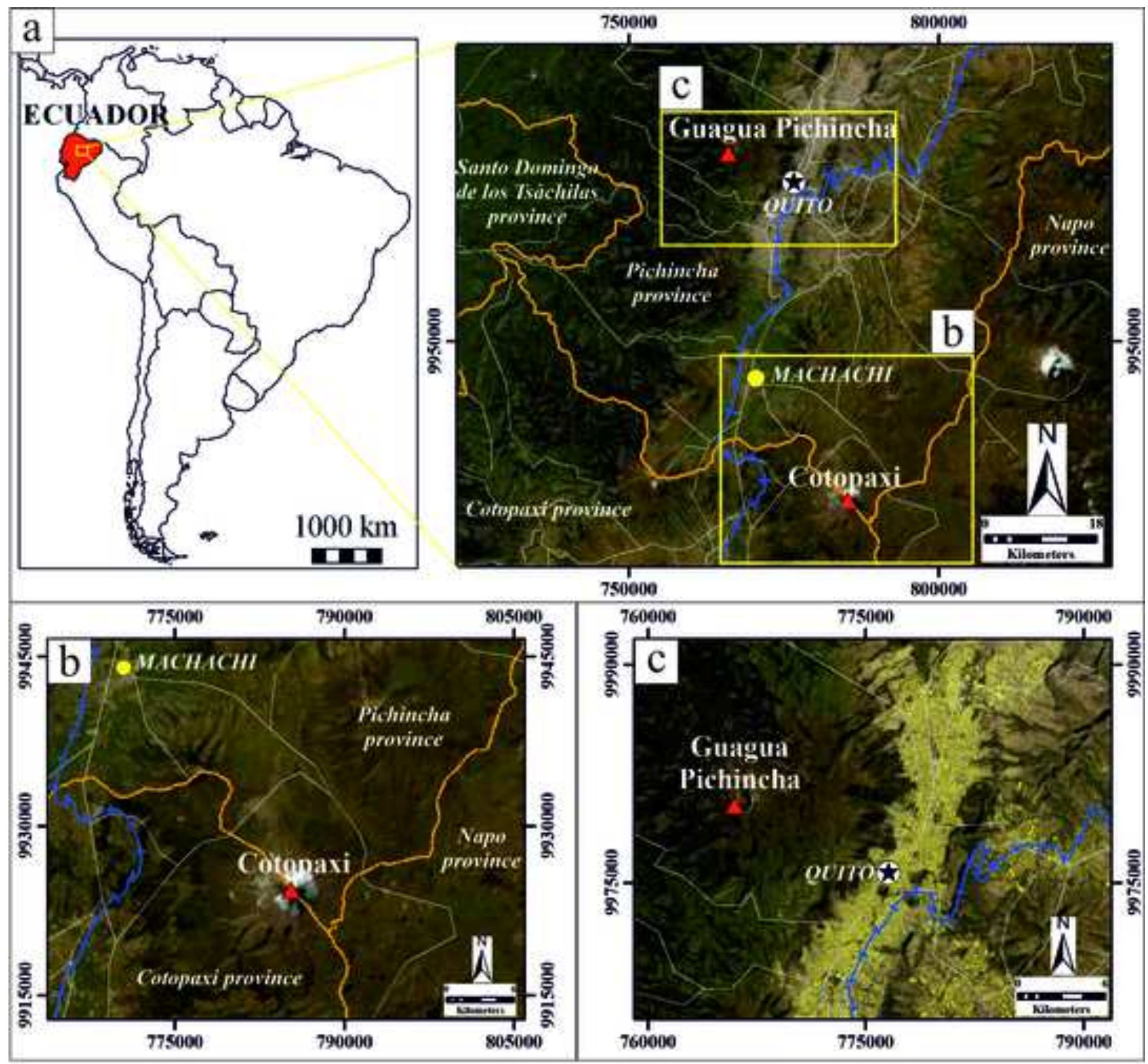

\section{Legend}

Province boundary
Town

Building
A Volcano

Railroad
Major road 


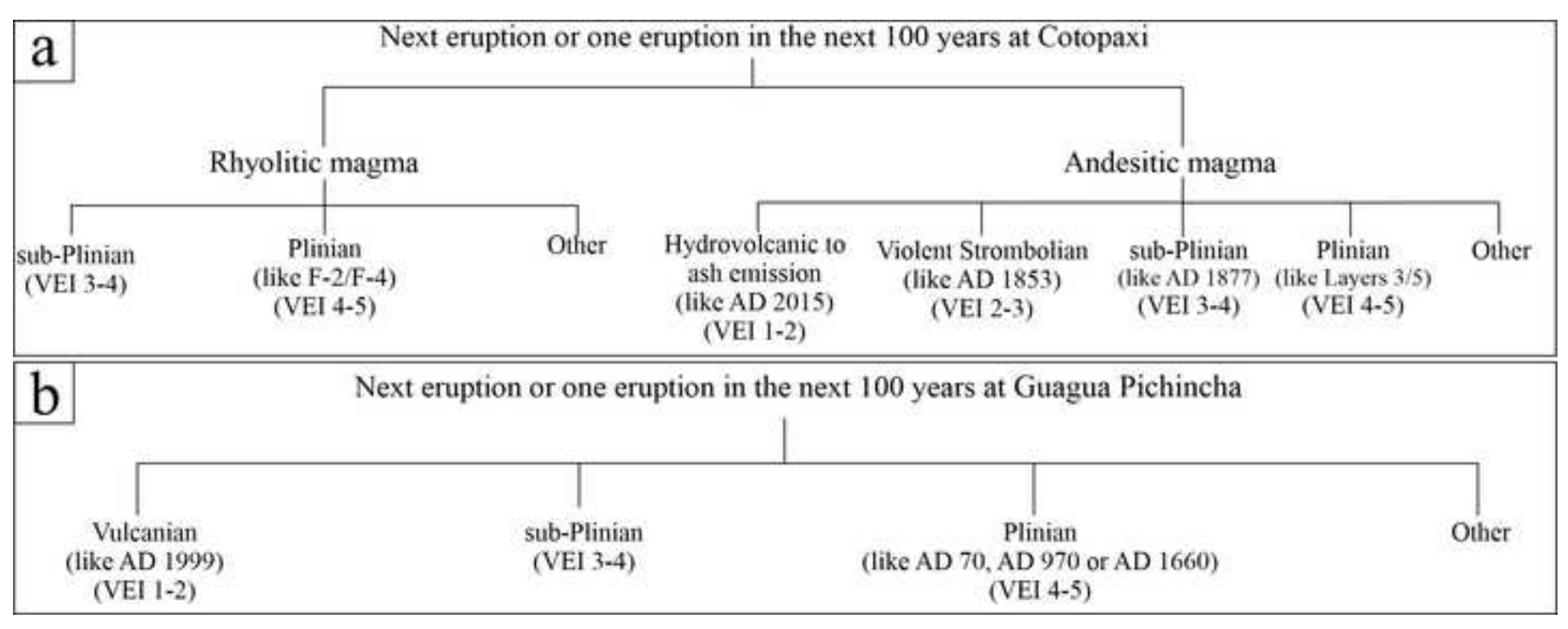




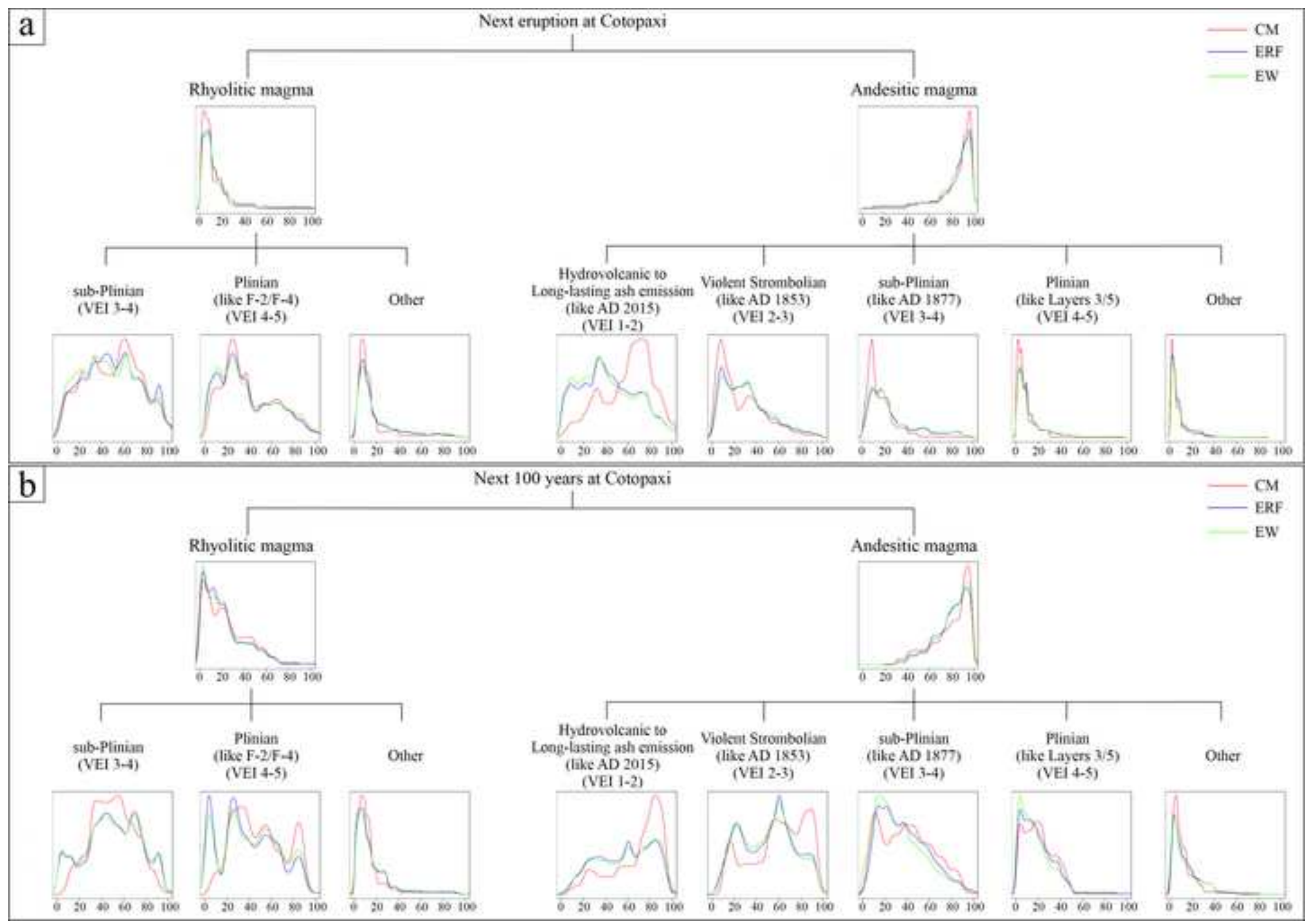




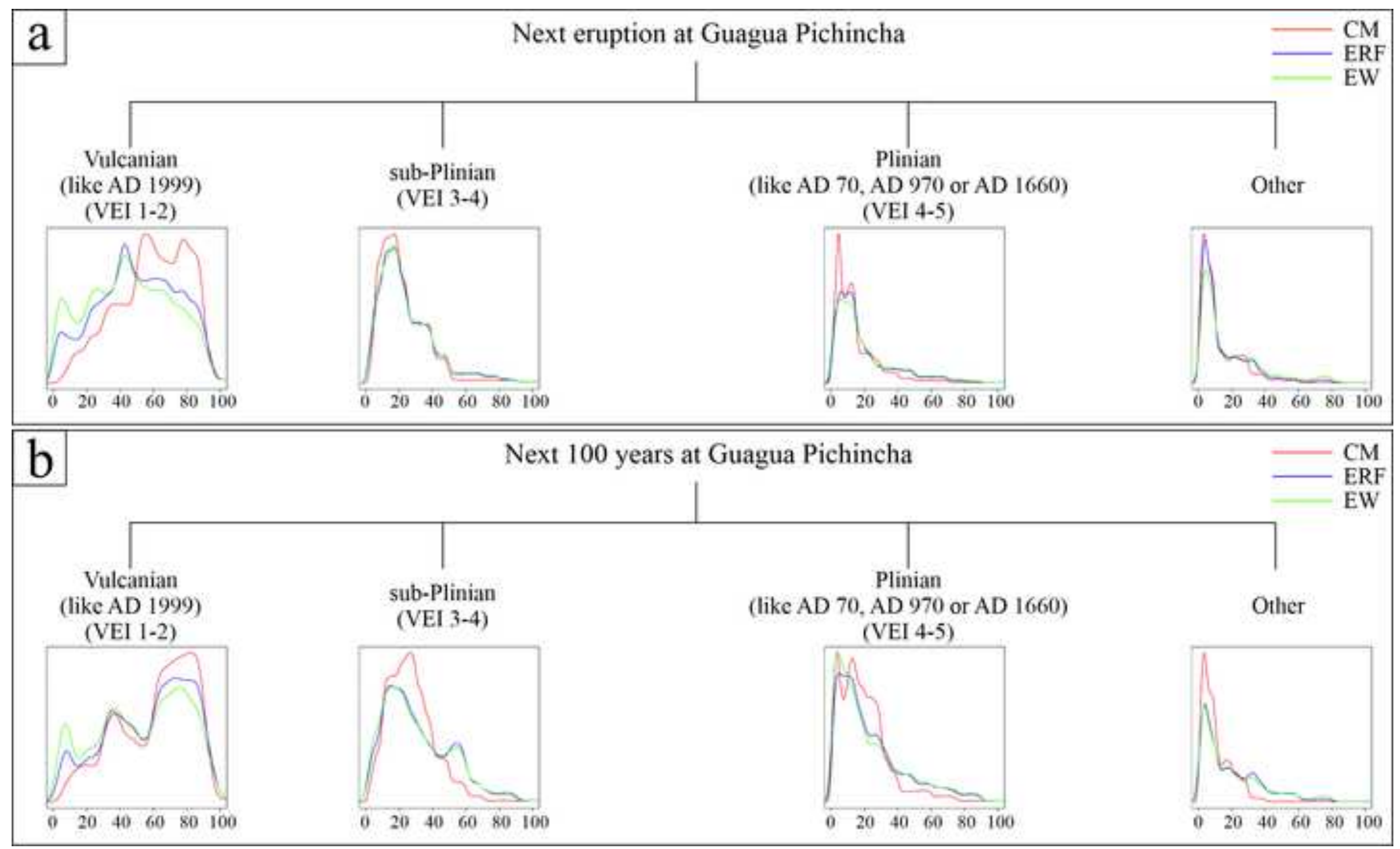




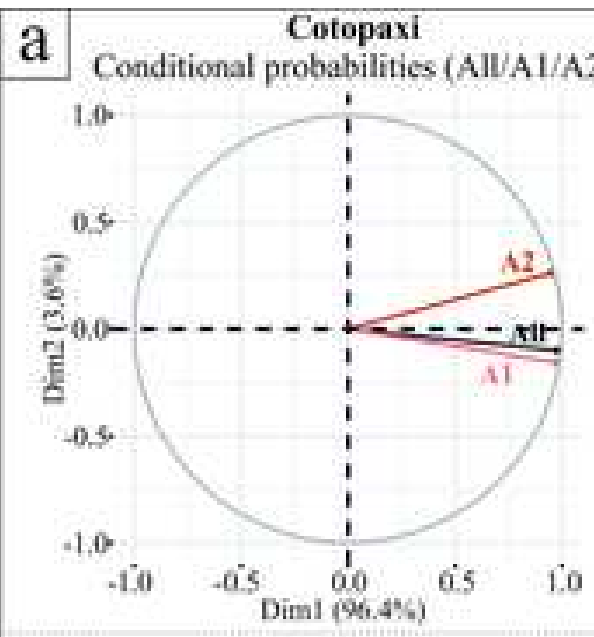

Cotopaxi

ESPs (Ali/AL/A2)

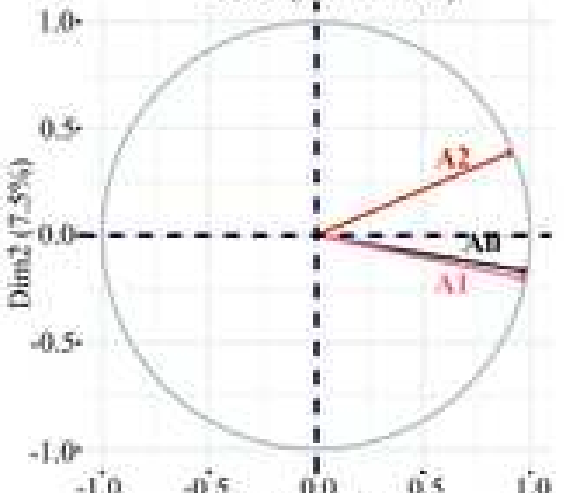

-1.0 -0.5 ${ }_{\operatorname{Dimt}}^{0.0}(925 \%$ i. 100

b Conditional probabilities (Al1/A1/A2)

1.0.

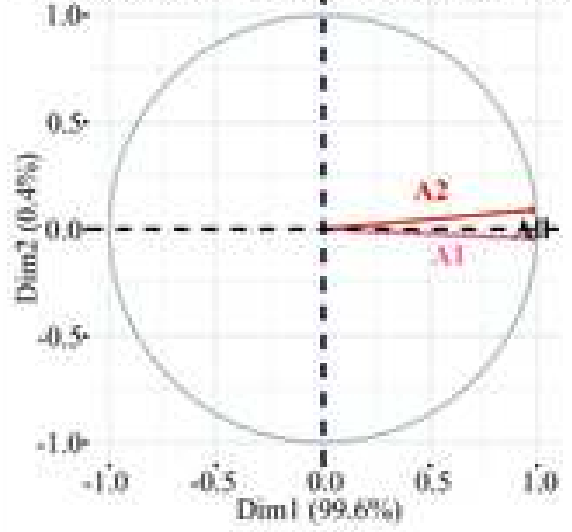

Guagua Pichincha

ESPs (All/A1/A2)

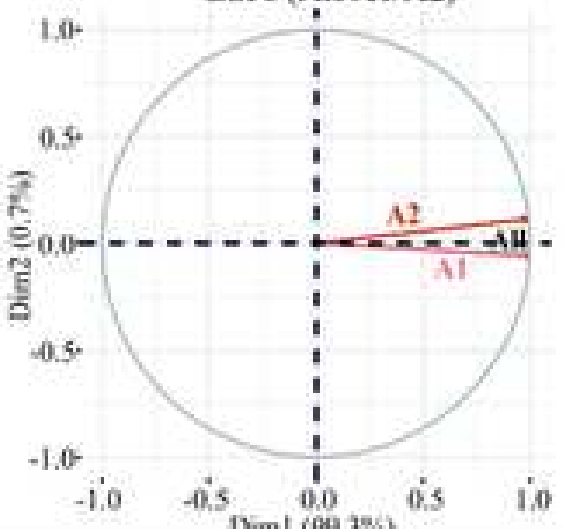

i.o tis o. of is i.s
Cotopaxi

Conditional probabilities (All/B1/B2)

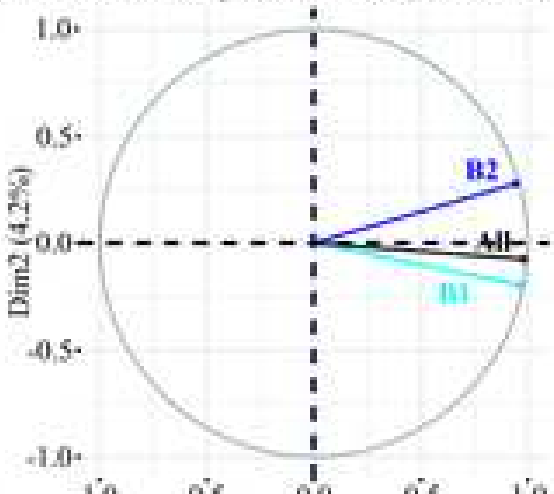

1.9.

Cotopaxi

ESPs (Alj/B1/B2)

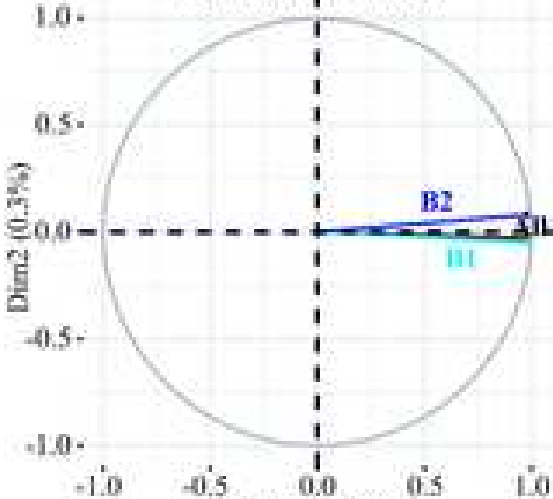

io -0.5 of is is

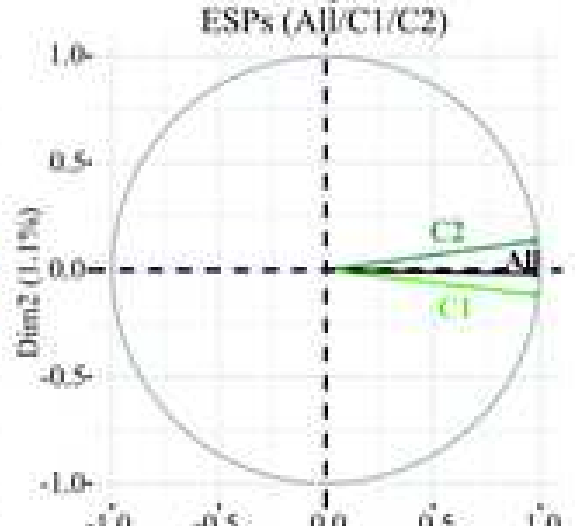
Diml $(99,7 \%)$

Cotopaxi

Conditional probabilities (All Cl/C2)

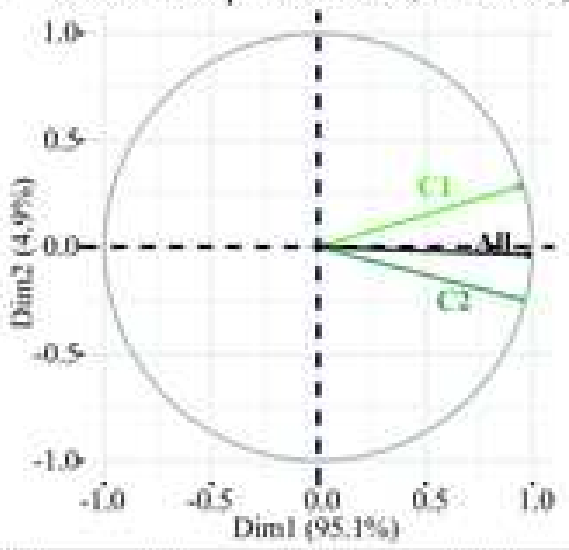

Cotopaxi

ESPs (Ali/C1/C2)

Diml (9895)
Guagua Pichincha

Guagua Pichincha

Conditional probabilities (Al1/B1/B2)

1.0 .

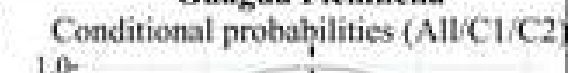

18

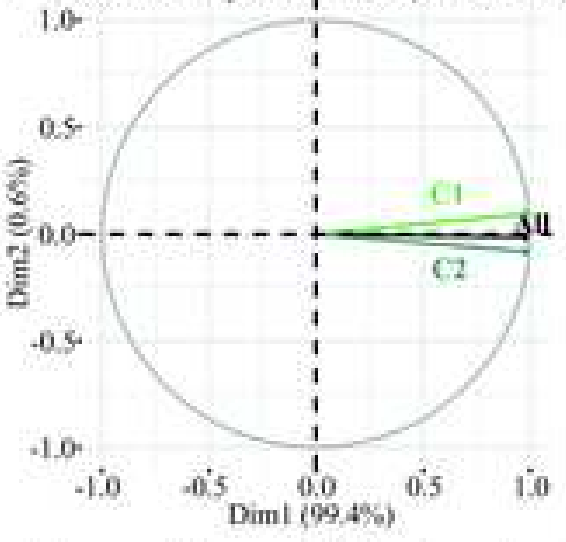

1.0.

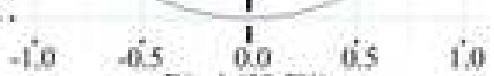

Dimi (99.5\%)

Guagua Pichincha
ESPs (All/B1/B2)
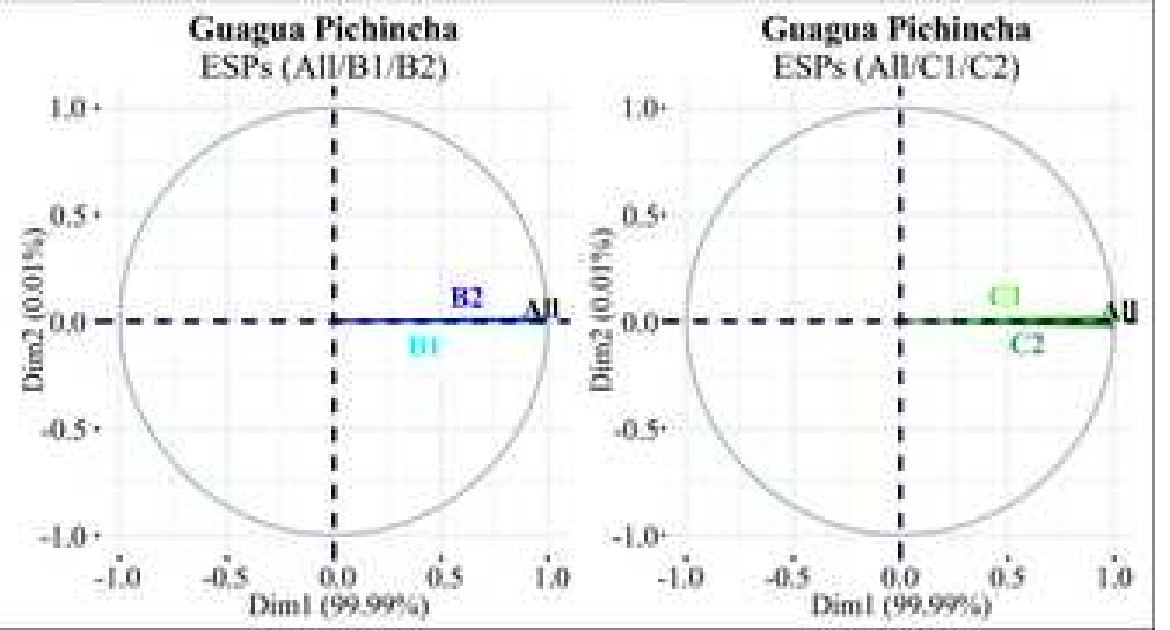

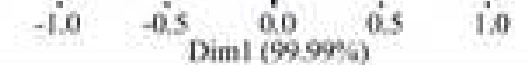

Guagua Pichincha
ESPs $(\mathrm{All} / \mathrm{C} 1 / \mathrm{C} 2)$ 


\begin{tabular}{|c|c|c|c|c|c|c|c|}
\hline $\begin{array}{c}\text { Eruptive } \\
\text { Cycle or } \\
\text { Eruption } \\
\text { Name } \\
\end{array}$ & $\begin{array}{c}\mathrm{N}^{\circ} \\
\text { eruptions }\end{array}$ & $\begin{array}{c}\text { DRE volume } \\
\left(\mathrm{km}^{3}\right)\end{array}$ & Age/Date & $\begin{array}{l}\text { Maximum } \\
\text { VEI }\end{array}$ & $\begin{array}{l}\text { Eruptive } \\
\text { style(s) }\end{array}$ & $\begin{array}{c}\text { Magma } \\
\text { composition }\end{array}$ & $\operatorname{Ref}(s)$ \\
\hline 2015 & 1 & 0.0001 & AD 2015 & $1-2$ & $\begin{array}{l}\text { Hydrovolcanic } \\
\text { to continuous } \\
\text { ash emission }\end{array}$ & & \\
\hline 1877 & 1 & $0.02-0.06$ & AD 1877 & 4 & SubPlinian & Andesitic & $1,2,3,4$ \\
\hline 1853 & 1 & $0.02-0.12$ & AD 1853 & $2-3$ & $\begin{array}{c}\text { Violent } \\
\text { Strombolian }\end{array}$ & & \\
\hline X/Layer 3 & 1 & 2.4 & $\sim 0.9 \mathrm{ka}$ & $4-5$ & Plinian & & \\
\hline Y/Layer 5 & 1 & 0.5 & $\sim 1.1 \mathrm{ka}$ & 4 & Plinian & & \\
\hline $\mathrm{F}-4$ & $>1$ & $1.59-8.3$ & $\sim 5.8 \mathrm{ka}$ & 5 & Plinian & Rhyolitic & 1 \\
\hline $\mathrm{F}-2$ & $>1$ & $2.37-8.6$ & $\sim 7.8 \mathrm{ka}$ & $?$ & Plinian & киуолте & 1 \\
\hline
\end{tabular}




\begin{tabular}{|c|c|c|c|c|c|c|}
\hline $\begin{array}{c}\text { Eruptive } \\
\text { Cycle } \\
\text { Name } \\
\end{array}$ & $\begin{array}{c}\mathbf{N}^{\circ} \\
\text { eruptions }\end{array}$ & $\begin{array}{c}\text { DRE } \\
\text { volume } \\
(\mathbf{k m 3})\end{array}$ & Age & \begin{tabular}{|c|} 
Maximum \\
VEI of \\
cycle \\
\end{tabular} & Eruptive style(s) & Refs \\
\hline 1999-2001 & $\sim 13$ & & $\begin{array}{l}\text { AD 1999- } \\
2001\end{array}$ & 0 to $1-2$ & $\begin{array}{c}\sim 5 \text { Vulcanian } \\
8 \text { Dome forming }\end{array}$ & \\
\hline Historic & 4 & $\begin{array}{l}>0.2 \text { (of } \\
\text { the largest } \\
\text { eruption) }\end{array}$ & $\begin{array}{l}\text { AD } 1660 \\
\text { (of the } \\
\text { largest } \\
\text { eruption) }\end{array}$ & $3-4$ & $\begin{array}{c}\text { Plinian } \\
\text { (of the largest } \\
\text { eruption) }\end{array}$ & $1,2,3$ \\
\hline $\mathrm{X}$ century & $>1$ & $\begin{array}{c}>>0.6 \\
\text { (of the } \\
\text { largest } \\
\text { eruption) }\end{array}$ & $\begin{array}{l}\text { AD } 970 \\
\text { (of the } \\
\text { largest } \\
\text { eruption) }\end{array}$ & 5 & $\begin{array}{c}\text { Plinian } \\
\text { (of the largest } \\
\text { eruption) }\end{array}$ & \\
\hline I century & 1 & $>0.5$ & $\mathrm{AD} 70$ & 4 & Plinian & \\
\hline
\end{tabular}




\begin{tabular}{|c|ccc|ccc|ccc|}
\hline \multirow{2}{*}{ Variable } & \multicolumn{9}{|c|}{ \% $^{\text {th }}$ /Median/95 } \\
\cline { 2 - 9 } & \multicolumn{3}{|c|}{ CM } & \multicolumn{3}{c|}{ ERF } & \multicolumn{3}{c|}{ EW } \\
\hline \% sub-Plinian Rhyolitic (NE) & $<0.1$ & $\mathbf{3 . 7}$ & 19 & $<0.1$ & $\mathbf{4 . 6}$ & 26 & $<0.1$ & $\mathbf{4 . 7}$ & 29 \\
\% Plinian Rhyolitic (NE) & $<0.1$ & $\mathbf{2 . 7}$ & 15 & $<0.1$ & $\mathbf{3 . 1}$ & 20 & $<0.1$ & $\mathbf{3 . 4}$ & 24 \\
\% Other type Rhyolitic (NE) & $<0.1$ & $\mathbf{0 . 9}$ & 7.5 & $<0.1$ & $\mathbf{1 . 4}$ & 12 & $<0.1$ & $\mathbf{1 . 6}$ & 14 \\
\% Hydr./Ash em. Andesitic (NE) & 13 & $\mathbf{4 4}$ & 71 & 1.8 & $\mathbf{2 8}$ & 57 & 1.9 & $\mathbf{2 6}$ & 56 \\
\% Violent Stromb. Andesitic (NE) & 1.3 & $\mathbf{1 5}$ & 43 & 1.9 & $\mathbf{1 8}$ & 47 & 2.0 & $\mathbf{1 9}$ & 48 \\
\% sub-Plinian Andesitic (NE) & 0.4 & $\mathbf{9 . 5}$ & 33 & 1.2 & $\mathbf{1 5}$ & 45 & 1.1 & $\mathbf{1 4}$ & 44 \\
\% Plinian Andesitic (NE) & $<0.1$ & $\mathbf{4 . 2}$ & 23 & 0.1 & $\mathbf{5 . 9}$ & 31 & $<0.1$ & $\mathbf{5 . 5}$ & 31 \\
\% Other type Andesitic (NE) & $<0.1$ & $\mathbf{3 . 5}$ & 25 & $<0.1$ & $\mathbf{4 . 0}$ & 26 & $<0.1$ & $\mathbf{4 . 0}$ & 27 \\
\hline \% sub-Plinian Rhyolitic (N100) & $<0.1$ & $\mathbf{7 . 3}$ & 40 & $<0.1$ & $\mathbf{6 . 5}$ & 41 & $<0.1$ & $\mathbf{6 . 0}$ & 41 \\
\% Plinian Rhyolitic (N100) & $<0.1$ & $\mathbf{6 . 7}$ & 41 & $<0.1$ & $\mathbf{4 . 3}$ & 36 & $<0.1$ & $\mathbf{4 . 6}$ & 37 \\
\% Other type Rhyolitic (N100) & $<0.1$ & $\mathbf{1 . 5}$ & 18 & $<0.1$ & $\mathbf{1 . 4}$ & 18 & $<0.1$ & $\mathbf{1 . 5}$ & 20 \\
\% Hydr./Ash em. Andesitic (N100) & $<0.1$ & $\mathbf{5 5}$ & 87 & $<0.1$ & $\mathbf{4 3}$ & 84 & $<0.1$ & $\mathbf{4 5}$ & 85 \\
\% Violent Stromb. Andesitic (N100) & $<0.1$ & $\mathbf{4 7}$ & 87 & $<0.1$ & $\mathbf{3 8}$ & 81 & $<0.1$ & $\mathbf{3 8}$ & 81 \\
\% sub-Plinian Andesitic (N100) & $<0.1$ & $\mathbf{2 8}$ & 75 & $<0.1$ & $\mathbf{2 5}$ & 72 & $<0.1$ & $\mathbf{2 2}$ & 73 \\
\% Plinian Andesitic (N100) & $<0.1$ & $\mathbf{1 4}$ & 43 & $<0.1$ & $\mathbf{1 2}$ & 48 & $<0.1$ & $\mathbf{1 1}$ & 51 \\
\% Other type Andesitic (N100) & $<0.1$ & $\mathbf{6 . 1}$ & 41 & $<0.1$ & $\mathbf{7 . 4}$ & 47 & $<0.1$ & $\mathbf{7 . 1}$ & 50 \\
\hline
\end{tabular}




\begin{tabular}{|c|c|c|c|c|c|c|c|c|c|}
\hline \multirow{2}{*}{ Variable } & \multicolumn{9}{|c|}{$\%-5^{\text {th }} /$ Median $/ 95^{\text {th }}$} \\
\hline & \multicolumn{3}{|c|}{ CM } & \multicolumn{3}{|c|}{ ERF } & \multicolumn{3}{|c|}{ EW } \\
\hline$\%$ Vulcanian (NE) & 4.7 & 55 & 81 & 0.5 & 45 & 77 & 0.3 & 40 & 76 \\
\hline$\%$ sub-Plinian (NE) & 1.8 & 18 & 55 & 1.0 & 20 & 60 & 0.3 & 19 & 60 \\
\hline$\%$ Plinian (NE) & 0.3 & 9.9 & 46 & 0.4 & 13 & 54 & 0.4 & 14 & 57 \\
\hline$\%$ Other type (NE) & $<0.1$ & 7.5 & 43 & $<0.1$ & 8.8 & 48 & $<0.1$ & 11 & 54 \\
\hline$\%$ Vulcanian (N100) & 5.5 & 66 & 94 & 1.6 & 62 & 96 & 1.2 & 56 & 96 \\
\hline$\%$ sub-Plinian (N100) & 2.1 & 25 & 63 & 0.9 & 26 & 83 & $<0.1$ & 26 & 81 \\
\hline$\%$ Plinian (N100) & 1.0 & 17 & 66 & $<0.1$ & 17 & 82 & $<0.1$ & 16 & 80 \\
\hline$\%$ Other type (N100) & $<0.1$ & 7.9 & 37 & 0.1 & 13 & 70 & $<0.1$ & 13 & 75 \\
\hline
\end{tabular}




\begin{tabular}{|c|c|c|c|c|c|c|c|c|c|}
\hline \multirow{2}{*}{ Variable } & \multicolumn{9}{|c|}{$5^{\text {th }} /$ Median $/ 95^{\text {th }}$} \\
\hline & \multicolumn{3}{|c|}{$\mathrm{CM}$} & \multicolumn{3}{|c|}{ ERF } & \multicolumn{3}{|c|}{ EW } \\
\hline $\begin{array}{c}\text { Mean duration sub-Plinian } \\
\text { Rhyolitic (minutes) }\end{array}$ & 15 & 170 & 6300 & 13 & 210 & 4000 & 10 & 210 & 4100 \\
\hline $\begin{array}{l}\text { Total mass tephra sub-Plinian } \\
\qquad \text { Rhyolitic }\left(10^{9} \mathrm{~kg}\right)\end{array}$ & 2.4 & 53 & 760 & 0.2 & 39 & 740 & 0.2 & 36 & 740 \\
\hline $\begin{array}{c}\text { Average plume height sub- } \\
\text { Plinian Rhyolitic }(\mathrm{km})\end{array}$ & 5.6 & 16 & 25 & 2.7 & 17 & 28 & 2.1 & 17 & 28 \\
\hline $\begin{array}{c}\text { Mean duration Plinian } \\
\text { Rhyolitic (minutes) }\end{array}$ & 27 & 340 & 13000 & 19 & 400 & 8900 & 15 & 330 & 8800 \\
\hline $\begin{array}{c}\text { Total mass tephra Plinian } \\
\text { Rhyolitic }\left(10^{9} \mathrm{~kg}\right)\end{array}$ & 8.8 & 410 & 7600 & 0.005 & 450 & 14000 & 0.002 & 450 & 35000 \\
\hline $\begin{array}{c}\text { Average plume height Plinian } \\
\text { Rhyolitic }(\mathrm{km})\end{array}$ & 10 & 24 & 40 & 7.8 & 26 & 40 & 6.5 & 26 & 40 \\
\hline $\begin{array}{c}\text { Mean duration Hyd./Ash em. } \\
\text { Andesitic (minutes) }\end{array}$ & 220 & 41000 & 1200000 & 52 & 48000 & 800000 & 35 & 44000 & 710000 \\
\hline $\begin{array}{c}\text { Total mass tephra Hyd./Ash } \\
\text { em. Andesitic }\left(10^{9} \mathrm{~kg}\right)\end{array}$ & 0.0001 & 0.8 & 110 & 0.0002 & 0.8 & 60 & 0.0001 & 0.6 & 58 \\
\hline $\begin{array}{c}\text { Average plume height } \\
\text { Hyd./Ash em. Andesitic }(\mathrm{km})\end{array}$ & 0.3 & 3.8 & 14 & 0.2 & 3.2 & 13 & 0.2 & 3.1 & 13 \\
\hline $\begin{array}{c}\text { Mean duration Violent Str. } \\
\text { Andesitic (minutes) }\end{array}$ & 6 & 42 & 6000 & 6 & 41 & 12000 & 6 & 46 & 320000 \\
\hline $\begin{array}{l}\text { Total mass tephra Violent Str. } \\
\qquad \text { Andesitic }\left(10^{9} \mathrm{~kg}\right)\end{array}$ & 0.01 & 6.0 & 92 & 0.004 & 1.5 & 74 & 0.004 & 0.8 & 71 \\
\hline $\begin{array}{c}\text { Average plume height Violent } \\
\text { Str. Andesitic }(\mathrm{km})\end{array}$ & 1.5 & 8.3 & 18 & 1.5 & 9.9 & 26 & 1.4 & 9.6 & 27 \\
\hline $\begin{array}{c}\text { Mean duration sub-Plinian } \\
\text { Andesitic (minutes) }\end{array}$ & 9 & 75 & 9400 & 9 & 79 & 5500 & 8 & 73 & 6000 \\
\hline $\begin{array}{l}\text { Total mass tephra sub-Plinian } \\
\text { Andesitic }\left(10^{9} \mathrm{~kg}\right)\end{array}$ & 1.2 & 34 & 430 & 0.05 & 21 & 270 & 0.04 & 18 & 290 \\
\hline $\begin{array}{c}\text { Average plume height sub- } \\
\text { Plinian Andesitic }(\mathrm{km})\end{array}$ & 6.6 & 18 & 25 & 7.9 & 19 & 28 & 7.4 & 19 & 28 \\
\hline $\begin{array}{c}\text { Mean duration Plinian } \\
\text { Andesitic (minutes) }\end{array}$ & 11 & 180 & 19000 & 12 & 200 & 11000 & 12 & 180 & 12000 \\
\hline $\begin{array}{c}\text { Total mass tephra Plinian } \\
\text { Andesitic }\left(10^{9} \mathrm{~kg}\right)\end{array}$ & 11 & 220 & 4200 & 0.07 & 320 & 9900 & 0.04 & 270 & 14000 \\
\hline $\begin{array}{c}\text { Average plume height Plinian } \\
\text { Andesitic }(\mathrm{km})\end{array}$ & 13 & 25 & 35 & 14 & 26 & 35 & 13 & 26 & 36 \\
\hline
\end{tabular}




\begin{tabular}{|c|c|c|c|c|c|c|c|c|c|}
\hline \multirow{2}{*}{ Variable } & \multicolumn{9}{|c|}{$5^{\text {th }} /$ Median $/ 95^{\text {th }}$} \\
\hline & \multicolumn{3}{|c|}{$\mathbf{C M}$} & \multicolumn{3}{|c|}{ ERF } & \multicolumn{3}{|c|}{ EW } \\
\hline Mean duration Vulcanian (minutes) & 0.9 & 14 & 2300 & 1 & 17 & 8800 & 1 & 19 & $2 \mathrm{E}+05$ \\
\hline Total mass tephra Vulcanian $\left(10^{9} \mathrm{~kg}\right)$ & 2E-04 & 1.6 & 71 & 2E-04 & 0.4 & 51 & $1 \mathrm{E}-04$ & 0.3 & 55 \\
\hline Average plume height Vulcanian ( $\mathrm{km})$ & 1.0 & 8 & 19 & 1.1 & 9.3 & 21 & 0.6 & 8.9 & 21 \\
\hline Mean duration sub-Plinian (minutes) & 9 & 88 & 6400 & 8 & 100 & 4300 & 6 & 96 & 4300 \\
\hline Total mass tephra sub-Plinian $\left(10^{9} \mathrm{~kg}\right)$ & 0.4 & 28 & 660 & 0.03 & 18 & 470 & 0.02 & 13 & 460 \\
\hline Average plume height sub-Plinian ( $\mathrm{km})$ & 6.9 & 17 & 25 & 7.9 & 18 & 27 & 7.4 & 18 & 28 \\
\hline Mean duration Plinian (minutes) & 11 & 190 & 13000 & 11 & 240 & 9200 & 9 & 210 & 9100 \\
\hline Total mass tephra Plinian $\left(10^{9} \mathrm{~kg}\right)$ & 1.6 & 170 & 3600 & 0.03 & 170 & 4400 & 0.03 & 140 & 6800 \\
\hline Average plume height Plinian $(\mathrm{km})$ & 13 & 24 & 34 & 14 & 26 & 34 & 13 & 25 & 34 \\
\hline
\end{tabular}




\begin{tabular}{|c|c|c|c|c|c|c|}
\hline \multirow{3}{*}{ Eruption Cotopaxi } & \multicolumn{6}{|c|}{ Mean values } \\
\hline & \multicolumn{3}{|c|}{ NE (\%): SUM=100 } & \multicolumn{3}{|c|}{$\mathrm{N100}(\%)$} \\
\hline & $\mathbf{C M}$ & ERF & EW & $\mathbf{C M}$ & ERF & EW \\
\hline sub-Plinian Rhyolitic & 5.9 & 7.7 & 8.1 & 12 & 11 & 11 \\
\hline Plinian Rhyolitic & 4.6 & 5.6 & 6.4 & 12 & 9.2 & 9.7 \\
\hline Other type Rhyolitic & 2.0 & 3 & 3.6 & 4.2 & 4.3 & 4.7 \\
\hline Hydr./Ash em. Andesitic & 44 & 28 & 27 & 51 & 43 & 44 \\
\hline Violent Stromb. Andesitic & 18 & 21 & 21 & 45 & 38 & 38 \\
\hline sub-Plinian Andesitic & 12 & 18 & 17 & 31 & 29 & 27 \\
\hline Plinian Andesitic & 6.9 & 9.4 & 9.1 & 17 & 17 & 16 \\
\hline Other type Andesitic & 6.8 & 7.2 & 7.5 & 11 & 13 & 14 \\
\hline \multirow{3}{*}{$\begin{array}{c}\text { Eruption Guagua } \\
\text { Pichincha }\end{array}$} & \multicolumn{6}{|c|}{ Mean values } \\
\hline & \multicolumn{3}{|c|}{ NE (\%): SUM=100 } & \multicolumn{3}{|c|}{ N100 (\%) } \\
\hline & CM & ERF & EW & CM & ERF & EW \\
\hline Vulcanian & 51 & 44 & 40 & 60 & 56 & 52 \\
\hline sub-Plinian & 22 & 24 & 24 & 28 & 32 & 32 \\
\hline Plinian & 14 & 18 & 19 & 21 & 25 & 24 \\
\hline Other type & 13 & 15 & 18 & 13 & 21 & 22 \\
\hline
\end{tabular}




\begin{tabular}{|c|c|c|c|c|c|c|c|c|c|}
\hline \multirow{3}{*}{ Eruption Cotopaxi } & \multicolumn{9}{|c|}{ Mean values } \\
\hline & \multicolumn{3}{|c|}{ Duration (min) } & \multicolumn{3}{|c|}{ Total mass fallout $\left(10^{9} \mathrm{~kg}\right)$} & \multicolumn{3}{|c|}{ Average plume height (km) } \\
\hline & $\mathbf{C M}$ & ERF & EW & $\mathbf{C M}$ & ERF & EW & $\mathbf{C M}$ & ERF & EW \\
\hline sub-Plinian Rhyolitic & 200 & 190 & 180 & 49 & 30 & 27 & 14 & 15 & 14 \\
\hline Plinian Rhyolitic & 370 & 340 & 290 & 270 & 150 & 120 & 22 & 23 & 22 \\
\hline Hydr./Ash em. Andesitic & 29000 & 24000 & 19000 & 0.5 & 0.4 & 0.2 & 3.2 & 2.7 & 2.6 \\
\hline Violent Stromb. Andesitic & 73 & 88 & 120 & 4.0 & 1.1 & 0.9 & 7.3 & 8.3 & 8.1 \\
\hline sub-Plinian Andesitic & 110 & 96 & 97 & 27 & 11 & 9.3 & 16 & 18 & 17 \\
\hline Plinian Andesitic & 230 & 210 & 190 & 240 & 180 & 140 & 24 & 25 & 25 \\
\hline \multirow{3}{*}{$\begin{array}{l}\text { Eruption Guagua } \\
\text { Pichincha }\end{array}$} & \multicolumn{9}{|c|}{ Mean values } \\
\hline & \multicolumn{3}{|c|}{ Duration (min) } & \multicolumn{3}{|c|}{ Total mass fallout $\left(10^{9} \mathrm{~kg}\right)$} & \multicolumn{3}{|c|}{ Average plume height (km) } \\
\hline & $\mathbf{C M}$ & ERF & EW & $\mathbf{C M}$ & ERF & EW & $\mathbf{C M}$ & ERF & EW \\
\hline Vulcanian & 25 & 30 & 41 & 0.4 & 0.2 & 0.2 & 6.6 & 7.2 & 6.3 \\
\hline sub-Plinian & 130 & 110 & 110 & 24 & 10 & 7.8 & 16 & 17 & 17 \\
\hline Plinian & 240 & 230 & 200 & 130 & 98 & 73 & 24 & 24 & 24 \\
\hline
\end{tabular}




\begin{tabular}{|c|c|c|c|c|c|c|c|}
\hline Eruption & $\begin{array}{l}\text { Magma } \\
\text { type }\end{array}$ & VEI & $\begin{array}{l}\text { Eruptive } \\
\text { style }\end{array}$ & $\begin{array}{l}\text { Duration } \\
\text { (min) }\end{array}$ & $\begin{array}{c}\text { Mass of } \\
\text { fallout } \\
\text { deposit } \\
\left(10^{9} \mathrm{~kg}\right)\end{array}$ & $\begin{array}{c}\text { Plume } \\
\text { height } \\
(\mathbf{k m})\end{array}$ & $\operatorname{Ref}(\mathbf{s})$ \\
\hline Redoubt (USA), 2009 & Andesitic & - & Vulcanian & 87 & 14 & 15 & 1 \\
\hline Soufrière Hills (Monsterrat, UK), 1997 & Andesitic & - & Vulcanian & 60 & 0.5 & 11 & 1 \\
\hline Lascar (Chile), 1993 & Andesitic & - & sub-Plinian & 2883 & 350 & 21 & 1,3 \\
\hline Ruapehu (New Zealand), June 1996 & Andesitic & 3 & sub-Plinian & 600 & 4.2 & 8.5 & 1,2 \\
\hline Nevado del Ruiz (Colombia), 1985 & Andesitic & 3 & - & 18 & - & 26 & 2 \\
\hline Spurr (USA), June 1992 & Andesitic & 3 & sub-Plinian & 264 & - & 14.5 & 1,2 \\
\hline Spurr (USA), August 1992 & Andesitic & 3 & sub-Plinian & 210 & 36 & 14 & 1,2 \\
\hline Spurr (USA), September 1992 & Andesitic & 3 & sub-Plinian & 216 & 39 & 14 & 1,2 \\
\hline Hekla (Iceland), 1970 & Andesitic & 3 & - & 120 & - & 14 & 2 \\
\hline Hekla (Iceland), 1980 & Andesitic & 3 & - & 300 & - & 15 & 2 \\
\hline Reventador (Ecuador), 2002 & Andesitic & 4 & - & 1320 & - & 17 & 2 \\
\hline Hekla (Iceland), 1947 (Brownish-grey ash) & Andesitic & 4 & - & 30 & - & 28 & 2 \\
\hline $\begin{array}{c}\text { Hekla (Iceland), } 1947 \text { (Brownish-black } \\
\text { ash) }\end{array}$ & Andesitic & 4 & - & 30 & - & 16 & 2 \\
\hline Soufrière St. Vincent 1902 & Andesitic & 4 & - & 150 & - & 14 & 2 \\
\hline El Chichón A (Mexico), 1982 & Andesitic & 5 & - & 300 & - & 20 & 2 \\
\hline El Chichón B and C (Mexico), 1982 & Andesitic & 5 & Plinian & 660 & 870 & 30 & 1,2 \\
\hline Hudson (Chile), 1991 & Andesitic & 5 & Plinian & 3783 & 3900 & 18 & 1,2 \\
\hline Santa Maria (Guatemala), 1902 & Andesitic & 6 & - & 1800 & - & 34 & 2 \\
\hline St. Helens (USA), 25 May 1980 & Dacitic & 3 & sub-Plinian & 30 & 42 & 10 & 2,4 \\
\hline St. Helens (USA), June 1980 & Dacitic & 3 & sub-Plinian & 30 & 45 & 9.6 & 2,4 \\
\hline Pinatubo (Philippines), 12 June 1991 & Dacitic & 3 & - & 38 & - & 17 & 2 \\
\hline St. Helens (USA), 18 May 1980 & Dacitic & 5 & Plinian & 540 & 630 & 13 & 2,4 \\
\hline Quizapu (Chile), 1932 & Dacitic & 6 & Plinian & 1080 & - & 28 & 2 \\
\hline Novarupta (USA), 1912 (Episode II) & Dacitic & 6 & Plinian & 1560 & 4800 & 22 & 2 \\
\hline Novarupta (USA), 1912 (Episode III) & Dacitic & 6 & Plinian & 600 & 4000 & 19 & 2 \\
\hline Pinatubo (Philippines), 15 June 1991 & Dacitic & 6 & Plinian & 540 & 5700 & 40 & 1,2 \\
\hline $\begin{array}{c}\text { Puyehue-Cordon Caulle (Chile), June } 2011 \\
\text { (Layers A-F) }\end{array}$ & Rhyolitic & $3-4$ & sub-Plinian & 1440 & 450 & 12 & 2,5 \\
\hline Chaitèn (Chile), May 2008 (Phases 1-4) & Rhyolitic & 4 & sub-Plinian & 10083 & 171 & 19 & 2,6 \\
\hline Askja (Iceland), March 1875 (Units B-D) & Rhyolitic & $4-5$ & $\begin{array}{l}\text { sub-Plinian } \\
\text { to Plinian }\end{array}$ & 480 & 989 & 19 & 4 \\
\hline Novarupta (USA), 1912 (Episode I) & Rhyolitic & 6 & Plinian & 960 & 4800 & 23 & 2,4 \\
\hline
\end{tabular}

